
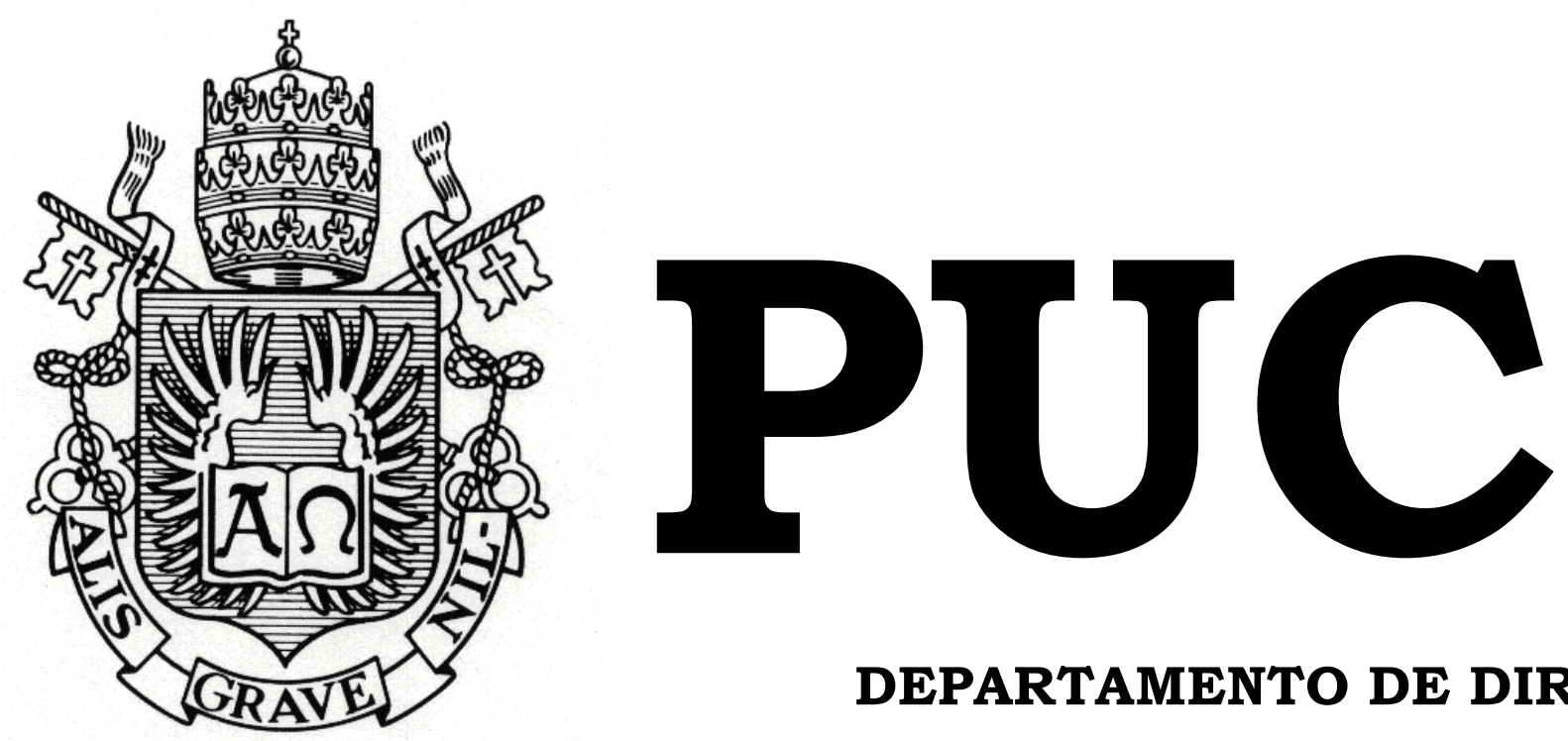

DEPARTAMENTO DE DIREITO

\title{
UMA ANÁLISE CRÍTICA ÀS RECENTES ALTERAÇÕES NA REGULAMENTAÇÃO DOS FUNDOS DE INVESTIMENTO NO MERCADO DE CAPITAIS BRASILEIRO
}

por

HUGO REINALDO BUENO NETO

ORIENTADOR: PROF. JULIAN FONSECA PEÑA CHEDIAK 2016.1

PONTIFÍCIA UNIVERSIDADE CATÓLICA DO RIO DE JANEIRO RUA MARQUÊS DE SÃO VICENTE, 225 - CEP 22453-900 RIO DE JANEIRO - BRASIL 


\title{
UMA ANÁLISE CRÍTICA ÀS RECENTES ALTERAÇÕES NA REGULAMENTAÇÃO DOS FUNDOS DE INVESTIMENTO NO MERCADO DE CAPITAIS BRASILEIRO
}

\author{
por \\ HUGO REINALDO BUENO NETO
}

Monografia apresentada ao

Departamento de Direito da Pontificia Universidade Católica do Rio de Janeiro (PUC-Rio) para a obtenção do Título de Bacharel em Direito.

Orientador: Prof. Julian Fonseca Peña Chediak 
Dedico o presente trabalho à minha família, pela serenidade e pelo apoio mesmo nos momentos em que as adversidades pareciam intransponíveis, e ao Mestre Julian Chediak, por ter sido verdadeiro norte ao longo de todo o processo fechamento desse ciclo. 
"Investir em conhecimento rende sempre os melhores juros."

\section{Benjamin Franklin}




\section{RESUMO}

O presente estudo visa não apenas a compreender os alicerces legais que estruturam e definem o regime jurídico dado aos fundos de investimento no ordenamento brasileiro, a partir de uma contextualização com a realidade socioeconômica e política vivida atualmente no Brasil, como também (e principalmente) promover um esforço de reflexão quanto às potenciais vantagens e desvantagens para a dinâmica do mercado financeiro nacional, por ocasião das mais recentes alterações decorrentes da edição da Instrução da CVM $\mathrm{n}^{\circ} 555$, de 17 de dezembro de 2014, conforme alterada, que foi responsável por modificar substancialmente a disciplina dada à matéria pela Instrução da CVM n ${ }^{\circ}$ 409, de 18 de agosto de 2004, conforme alterada. Sendo inegável a relevância do fundo de investimento, enquanto veículo de concentração e aplicação de recursos, proteção patrimonial e acesso ao mercado pelos mais diversos perfis de investidor, objetiva-se, dessa forma, desenvolver uma análise crítica do novo tratamento dado ao referido instituto pela regulamentação emanada da CVM a partir de uma projeção de seus efeitos no funcionamento do mercado de capitais brasileiro. Por esses meios, busca-se atingir o fim de avaliar se a nova regulamentação impulsiona os mercados financeiro e de capitais brasileiros, imersos em um cenário de hostil competitividade por conta da pluralidade de mercados relevantes e de vertiginosa intensificação do fluxo de recursos, pessoas e informações a nível global, no sentido de promover maior confiabilidade e eficiência a seus agentes.

Palavras-chave: Mercado de capitais. Fundos de investimento. Regime jurídico. Instrução CVM 555. Instrução CVM 409. 


\begin{abstract}
This study aims not only to understand the legal foundations that shape and define the legal treatment given to investment funds in Brazilian law system, as of a context of socioeconomic and political reality currently experienced in Brazil, but also (and mainly) in order to encourage an effort of reflection about the potential advantages and disadvantages to the dynamics of the domestic financial market, arising from the most recent changes related to the issuance of the Instruction of Comissão de Valores Mobiliários (CVM, the Brazilian Exchange Commission) No. 555, dated as of December 17th, 2014, as amended, which was responsible for modifying substantially the discipline given to the matter by Instruction of CVM No. 409, dated as of August 18th, 2004, as amended. Being undeniable the relevance of the investment fund, as a vehicle of concentration and application of resources, asset protection and market access by various investor profiles, this work seeks to develop a critical analysis of the new treatment applicable to this legal institute by the new rules from CVM by projecting their effects on the functionality of the Brazilian capital market. By these means, one pursues to achieve the goal of assessing whether the new regulation drives the Brazilian financial and capital markets, immersed in a hostile and competitive landscape due to the plurality of relevant markets and a vertiginous intensification of capital, people and information flows around the globe, in the direction of promoting greater reliability and efficiency to its agents.
\end{abstract}

Keywords: Capital market. Investment funds. Legal treatment. Instruction CVM No. 555. Instruction CVM No. 409. 


\section{SUMÁRIO}

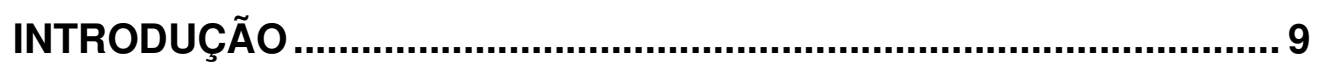

1 FUNDOS DE INVESTIMENTO: NOÇÕES PRELIMINARES.................11

1.1 INSTITUIÇÕES DE INVESTIMENTO COLETIVO …….........................11

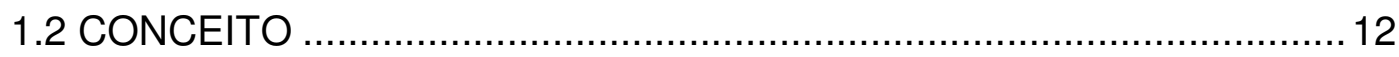

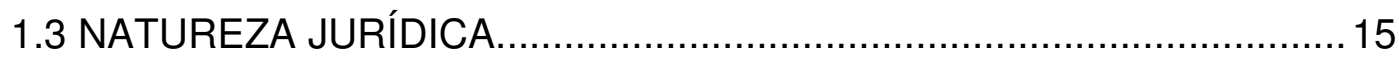

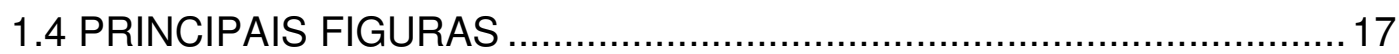

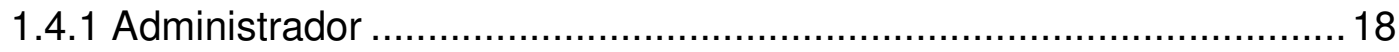

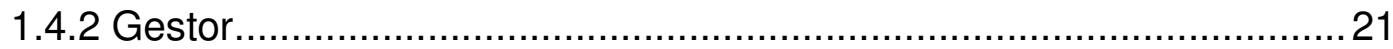

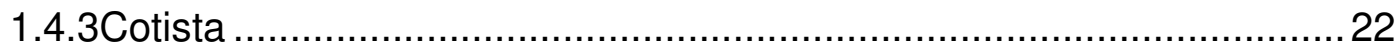

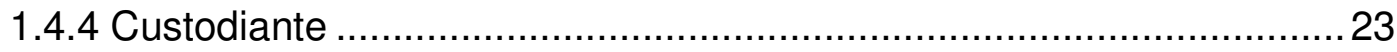

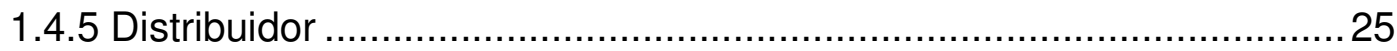

1.5 CLASSIFICAÇÃO 25

2 CONTEXTUALIZAÇÃO SOCIOECONÔMICA E POLÍTICA ………....... 30

2.1 O SISTEMA CAPITALISTA MODERNO ………................................. 30

2.2 O ATUAL CENÁRIO ECONÔMICO-POLÍTICO MUNDIAL ......................35

2.2.1 O mundo multipolar e a insurgência dos mercados emergentes $\quad 36$

2.3 O ATUAL CENÁRIO SOCIOECONÔMICO E POLÍTICO NO BRASIL 39

3 O DESENVOLVIMENTO HISTÓRICO DOS FUNDOS DE

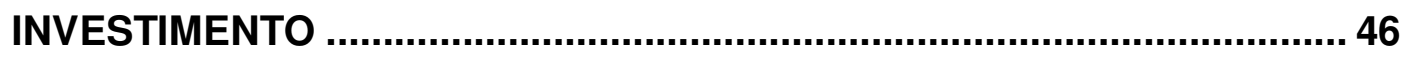

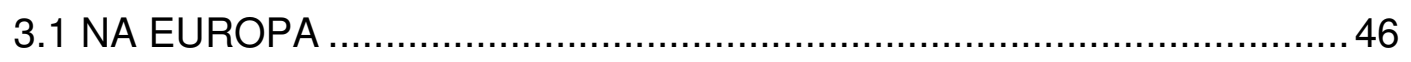

3.2. NOS ESTADOS UNIDOS DA AMÉRICA …..........................................53

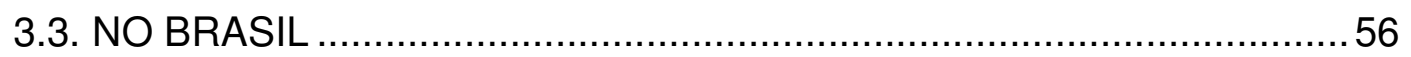

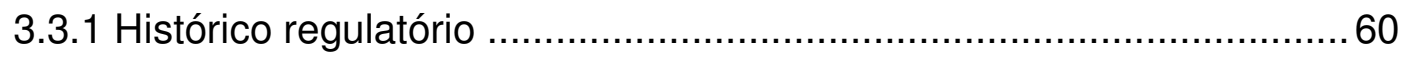

4 A INSTRUÇÃO DA CVM № 555, DE 17 DE DEZEMBRO DE $2014 \ldots 66$

5 POTENCIAIS REFLEXOS PARA O MERCADO FINANCEIRO........... 73 
CONCLUSÃO

80

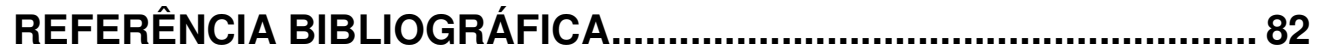




\section{LISTA DE SIGLAS}

ANBIMA - Associação Brasileira das Entidades dos Mercados Financeiros e de Capitais

BC - Banco Central do Brasil

CVM - Comissão de Valores Mobiliários

IBGE - Instituto Brasileiro de Geografia e Estatística

IPCA - Índice Nacional de Preços ao Consumidor Amplo

SELIC - Sistema Especial de Liquidação e Custódia 


\section{INTRODUÇÃO}

O presente trabalho foi elaborado não somente no intuito de apresentar o atual regramento dispensado aos fundos de investimento pelas autoridades regulatórias do mercado de capitais brasileiro, mas também a partir de um esforço no sentido de tentar antever, baseando-se em experiências passadas, os reflexos esperados pelo mercado em razão de tais mudanças normativas.

Não há, pois, qualquer dúvida que uma predição assertiva acerca dos efeitos futuros da nova regulamentação para os fundos de investimento no Brasil, condensada na Instrução CVM 555, pressupõe uma análise minuciosa da trajetória percorrida pela sociedade brasileira até que fosse possível estruturar um mercado financeiro sólido e maduro, ao espelho das práticas adotadas pelos mercados de economias desenvolvidas.

Adicionalmente a essa análise de nosso passado recente, é um dos pilares desta exposição evidenciar o contraste entre as diferentes soluções adotadas por juristas de outros ordenamentos para saciar a necessidade de seus respectivos mercados em relação às ferramentas (ou veículos) jurídicos pensados para viabilizar uma forma prática de realizar investimentos e aplicações de modo coletivo, sendo, com efeito, apresentadas as diferentes circunstâncias históricas nas quais o desenvolvimento de tais institutos se inseriu.

Nesse sentido, as ideias expostas nos próximos Capítulos estão organizadas basicamente em cinco principais pontos: (i) apresentar noções gerais sobre o fundo de investimento enquanto instituto jurídico; (ii) traçar um panorama socioeconômico e político, de modo a (iii) dar contorno ao processo de desenvolvimento da indústria de fundos de investimento no Brasil e no mundo, apresentando suas diferentes fases normativas do passado; 
(iii) finalmente, indicar as alterações advindas da edição da Instrução CVM 555; e (iv) os reflexos esperados pelo mercado em razão de tais alterações.

Busca-se, dessa forma, desenvolver uma análise crítica apurada das possíveis consequências desse novo tratamento dispensado pelo regulador aos fundos de investimento, instrumento de importância ímpar na dinâmica do mercado de capitais brasileiro nos dias atuais. 


\section{FUNDOS DE INVESTIMENTO: NOÇÕES PRELIMINARES}

O presente trabalho busca compreender os efeitos para o mercado das alterações advindas da edição da nova norma geral que disciplina os fundos de investimento no Brasil. No entanto, de nada valeria tal esforço sem que antes fosse feita a correta apresentação do fundo de investimento enquanto instituto jurídico, definindo seus principais aspectos e características, sem os quais uma compreensão holística do instituto se revelaria impossível.

Nesse sentido, os próximos itens são dedicados a expor breves considerações acerca das características elementares dos fundos de investimento, estabelecidas vezes pela regulamentação, vezes pela doutrina, na tentativa de projetar maior dimensão e aprofundamento a seu conceito. Assim, serão abordadas questões sobre as instituições de investimento coletivo, enquanto gênero em que o fundo de investimento está incluído, sua natureza jurídica, figuras atuantes no funcionamento de um fundo e as classificações emanadas de instituições de regulação e autorregulação do mercado de capitais. Dessa forma, será possível auferir com maior precisão se as alterações regulamentares recentes estão em concordância com as diversas facetas de um fundo de investimento, quando compreendido como forma jurídica complexa e concentradora dos mais variados feixes de direitos e deveres.

\subsection{INSTITUIÇÕES DE INVESTIMENTO COLETIVO}

Faz-se mister atribuir ao presente trabalho considerações não apenas em relação aos fundos de investimento enquanto categoria jurídica isolada, mas também às entidades anteriores ao nascimento do fundo de investimento, haja vista que a gênese deste, enquanto instituto jurídico, foi fortemente influenciada pela existência daquelas. Dessa forma, ainda que o surgimento dos fundos de 
investimento e sua popularização seja decorrente, em grande parte, da tentativa de atender às necessidades do mercado por modalidades de investimento coletivo eficazes, a análise apurada da espécie exige preliminarmente a devida apresentação de uma categoria mais abrangente em termos de solução de investimento: as instituições de investimento coletivo.

O que se buscava atingir com tais estruturas era maior eficiência para as novas demandas de serviços financeiros que surgiram ao longo da modernidade. Os agentes de mercado visavam, portanto, a estabelecer entidades que possibilitassem: (i) o fácil resgate dos recursos investidos; (ii) a diluição do risco do investimento entre os participantes em razão de uma maior diversidade de aplicações; e (iii) maior eficiência fiscal. De modo a atingir tais objetivos, no Reino Unido, estabeleceu-se a figura do investment trust (vide item 3.1 abaixo), revestido da forma jurídica de unit trust.

Embora não haja previsão legal para as instituições de investimento coletivo no ordenamento brasileiro, seu conceito começou a ser debatido por juristas britânicos e a exposição de seus principais aspectos se faz elementar para o esforço de compreender, de forma precisa, a evolução dos fundos de investimento no Brasil.

\subsection{CONCEITO}

O conceito genérico de fundo de investimento consiste na ideia de uma entidade jurídica que emite cotas no intuito de destinar os recursos decorrentes de sua subscrição por investidores à aplicação em ativos financeiros. Nesse sentido, via de regra, a participação em um fundo de investimento se dá mediante a integralização de cotas de sua emissão pelo investidor, que passa, então, a ser um cotista do fundo. A partir dos recursos angariados com a distribuição de tais 
cotas no mercado, o fundo de investimento, de acordo com suas políticas de investimento e de risco, realiza operações envolvendo ativos financeiros.

Vale frisar que, neste contexto, não são estabelecidas quaisquer relações societárias entre o fundo e seus cotistas. Assim como ocorre com o administrador e o gestor, os cotistas se vinculam ao fundo de investimento estabelecendo relações jurídicas de caráter contratual. Isso se explica pelo fato de que, nos tipos societários, o condão, que vincula ambas as partes, nasce e é reforçado por um fator afetivo (affectio) que se ausenta para os fundos de investimento. Inexistente esse viés de pessoalidade (que, destaca-se, é fundamental na condução da atividade empresarial), não há que se falar em relação societária, e sim de contrato. Os cotistas se filiam ao fundo sem interesse em quaisquer singularidades partilhadas entre si.

Os interesses do fundo e, em última instância dos cotistas, são representados pela instituição administradora, ao passo que a tomada de decisão de investimento pertence à alçada da instituição gestora, quando contratada. Os fundos de investimento, dessa forma, proporcionam aos investidores expectativa de rentabilidade, diversificação de carteira, mitigação do risco ao investir e orientação especializada na tomada de decisão de investimento.

Mais do que isso, em termos mercadológicos, o instituto do fundo de investimento merece atenção especial por representar uma alternativa prática de acesso, por pequenos investidores, geralmente inexperientes, ao mercado de capitais, tornando possível a composição de uma carteira de investimento sofisticada, composta de aplicações financeiras diversas, o que mitiga a exposição do investidor aos riscos do investimento e do mercado, além de viabilizar que tais pequenos investidores colham os resultados de operações que, por sua complexidade, não teriam sido feitas por cada indivíduo isoladamente. 
A esse fator da praticidade, alia-se, ainda, como ponto de vantagem auferido aos fundos de investimento, toda a complexidade que envolve sua estrutura administrativa, vez que se sustenta a partir da atuação de diversas figuras de mercado, como, por exemplo, o administrador, o gestor, a instituição custodiante e o distribuidor (vide item 1.4 abaixo).

Ainda nessa linha de raciocínio, um terceiro atrativo responsável por dar notoriedade aos fundos de investimento consiste na maior probabilidade de o investidor ter o risco de seu investimento mitigado. Afinal, o investidor comum, dispondo de montante modesto para aplicação, não poderia compor uma carteira tão diversificada quanto um fundo de investimento que reúne as poupanças de diversos pequenos investidores. Seguindo essa lógica, compreende-se que, em tese, a medida que se diversifica a carteira de um fundo, maior a possibilidade de que os ganhos de determinados ativos amorteçam as perdas dos demais. Obtém-se, assim, menor exposição aos riscos de mercado.

Dessa forma, proporcionando, ao mesmo tempo, (i) simplicidade para que até os investidores mais leigos possam acessar o mercado financeiro; (ii) sofisticação na administração do fundo e seus ativos, a partir de uma complexa engrenagem administrativa, da qual participam diversas instituições especializadas na tomada consciente de decisão investimento; e (iii) a mitigação do risco de investimento mediante a diversificação da carteira, o fundo de investimento, enquanto modalidade de investimento coletivo, já se encontra amplamente consolidado nas economias maduras. No Brasil, esse nicho vem crescendo vertiginosamente nas últimas três décadas (vide item 2.3 abaixo).

Por essa razão, tal entidade, não apenas enquanto artifício jurídico, mas também como fenômeno econômico, deve ser analisada com maior minúcia. 


\subsection{NATUREZA JURÍDICA}

Abordar o conceito de fundo sem, contudo, definir sua natureza jurídica não fornece o suporte teórico suficiente para uma análise aprofundada do instituto em questão. Por essa razão, deve-se primeiramente atentar para o posicionamento da doutrina sobre o assunto. Embora atualmente haja um entendimento majoritário, pode-se afirmar que há cinco principais teorias aceitas pela doutrina ao se indagar qual é a natureza jurídica de um fundo de investimento. São elas: (i) Teoria da Organização Associativa; (ii) Teoria da Comunidade de Bens não Condominial; (iii) Teoria da Propriedade em Mão Comum; (iv) Teoria da Propriedade Fiduciária; e (v) Teoria Condominial.

A primeira, mais distante da teoria dominante, prevê que o fundo de investimento se apresenta como um tipo de sociedade. Pela Teoria da Organização Associativa, uma vez presentes alguns requisitos básicos para a identificação de um tipo societário, quais sejam, a distribuição dos resultados, a constituição para o exercício regular de atividade econômica e a integralização por meio de bens ou serviços, um fundo deve receber o mesmo tratamento legal que aquele destinado às sociedades.

A Teoria da Comunidade de Bens não Condominial, por sua vez, preconiza que os fundos de investimento se tratam de uma universalidade de direito, sendo, portanto, aplicável o mesmo tratamento dispensado à herança, por exemplo. Cabe destacar que a universalidade de direito, assim como a copropriedade, representa uma das modalidades de bens coletivos.

Por outro lado, de acordo com a Teoria da Propriedade em Mão Comum, a relação entre o fundo de investimento e seus cotistas, assim como o direito de propriedade destes sobre aquele, deve ser entendida como uma relação de 
propriedade em mão comum, instituto criado por juristas alemães paralelo à comunhão de bens da lei civil brasileira. De acordo com essa corrente, de encontro ao regime aplicável ao condomínio, há uma vinculação recíproca entre todas as partes envolvidas na relação jurídica em que se baseia tal comunhão. Tem-se, portanto, maior foco na noção de coletividade do que o indivíduo.

Já a Teoria da Propriedade Fiduciária, ao seu turno, consagra a ideia de que os bens e direitos que integram o patrimônio do fundo de investimento são de propriedade da instituição administradora em regime fiduciário, devendo esta, portanto, geri-los no melhor interesse dos investidores. Conforme leciona Ricardo Freitas dos Santos, "essa teoria sustenta pertencer a propriedade fiduciária do fundo a quem exercer seu papel de administrador, pois este está investido dos poderes que corresponderiam ao titular do direito de domínio", de modo que "a relação entre o administrador e os cotistas estaria representada pela figura do mandato, não existindo, para estes últimos, qualquer direito real sobre o fundo".

Por fim, a Teoria Condominial, que prevaleceu no sistema pátrio, consiste na ideia de que as características intrínsecas a um fundo de investimento e as relações estabelecidas entre este os titulares das cotas de sua emissão o aproximam do conceito de condomínio, principalmente no que tange aos direitos decorrentes da propriedade da cota enquanto fração ideal do conjunto de bens que constitui tal comunhão. Tanto para o cotista, quanto para o condômino, são assegurados direitos de copropriedade, restando nítido que a relação jurídica nessa situação se limita ao vínculo de propriedade estabelecido entre o titular da cota e a coisa em si, da qual decorrem, portanto, os direitos reais sobre o conjunto de bens e direitos compreendidos no fundo. 
E dessa forma ficou positivado na regulamentação. Conforme define a Instrução CVM 555, o conceito de fundo de investimento, nos termos de seu artigo $3^{\circ}$, consiste em "uma comunhão de recursos, constituída sob a forma de condomínio, destinado à aplicação em ativos financeiros”. Preliminarmente, deve-se ater ao fato de que o regulador impôs, expressamente, que o fundo de investimento deva assumir a forma de condomínio, desprovido de personalidade jurídica e constituído para reunir recursos com destinação à composição de carteiras de aplicação nos mais diversos ativos financeiros ${ }^{1}$.

Como já esclarecido anteriormente (vide item 1.2 acima), não se trata, portanto, de uma relação societária, que vincula as partes integrantes de tal estrutura entre si, como prevê a Teoria da Organização Associativa, nem tão pouco se encaixa na definição legal qualquer das demais teorias apresentadas neste Capítulo, restando indubitável que, para o ordenamento brasileiro, adotouse a Teoria Condominial para definir a natureza jurídica de um fundo de investimento.

\subsection{PRINCIPAIS FIGURAS}

Embora os fundos de investimento atuais possam adotar as mais diversas formas e cumprir as mais distintas finalidades de investimento em termos mercadológicos (vide item 1.5 abaixo), ao estudá-los com maior atenção, resta nítido que há determinados aspectos essenciais, comuns a todas as classificações de fundo, e que, por essas razões, merecem breves considerações.

\footnotetext{
${ }^{1}$ São exemplos: títulos da dívida pública, debêntures e demais títulos de renda fixa, ações, notas promissórias e demais títulos de crédito, direitos creditórios, derivativos, cotas de outros fundos, créditos imobiliários, títulos e valores mobiliários negociados no exterior, títulos securitizados,
} 
Conforme serão apresentados individualmente nos itens subsequentes, tais figuras são responsáveis por constituir e/ou manter um fundo de investimento em funcionamento, com uma matriz de responsabilidades e atribuições definida, por vezes, inclusive, por força da regulamentação aplicável. Nesse sentido, somente compreendendo a atuação prática e o regramento auferido a tais personagens isoladamente, pode-se formar um quadro analítico preciso do fundo de investimento enquanto instituição orgânica, interdependente, feixe concentrador de relações jurídicas diversas e dotada de uma complexa estrutura de governança.

\subsubsection{Administrador}

A primeira figura envolvida no funcionamento de um fundo de investimento é o administrador. A tal cargo recai a responsabilidade de efetivamente representar o fundo, praticando todos os atos necessários à sua administração, como, por exemplo, a contratação das demais instituições que prestam serviços ao fundo ${ }^{2}$ e a sua representação em procedimentos judiciais e perante autoridades governamentais.

Nos termos do artigo 78, caput, da Instrução CVM 555, a definição da atividade de administração do fundo consiste no "conjunto de serviços relacionados direta ou indiretamente ao funcionamento e à manutenção do fundo, que podem ser prestados pelo próprio administrador ou por terceiros por ele contratados, por escrito, em nome do fundo".

\footnotetext{
${ }^{2}$ De acordo com o disposto no artigo 78, parágrafo $2^{\circ}$, da Instrução CVM 555, o administrador pode contratar os seguintes serviços em nome do fundo: gestão da carteira do fundo; consultoria em investimentos; atividades de tesouraria, controle e processamento de ativos do fundo, distribuição de cotas, escrituração da emissão e resgate de cotas, custódia de ativos financeiros, classificação de risco por agência de classificação de risco de crédito e formador de mercado.
} 
Sua atuação possui tamanha relevância para a existência de um fundo de investimento que a sua constituição se dá por meio de deliberação do administrador, aprovando, neste ato, o seu regulamento, conforme instrui o artigo $6^{\circ}$ da Instrução CVM 555. Adicionalmente, cabe ao administrador a obrigação de prestar eventuais esclarecimentos à CVM quanto ao fundo, bem como de divulgar aos cotistas e ao mercado em geral informações relativas ao fundo ${ }^{3}$, em conformidade com o que dispõe a regulamentação aplicável.

Podem exercer a função de administrador de um fundo de investimento tanto pessoas naturais, quanto pessoas jurídicas, desde que observados determinados requisitos, dentre eles a obtenção a autorização da CVM para tanto, nos termos da Instrução da CVM nº 558, de 26 de março de 2015. Cabe a ressalva, no entanto, de que a regulamentação específica de cada classificação de fundo de investimento pode exigir que a função de administração do fundo seja exercida exclusivamente por pessoas jurídicas, ou, até mesmo, por instituições integrantes do sistema de distribuição de valores mobiliários, conforme define o artigo $15^{4}$ da Lei $n^{\circ} 6.385$, de 7 de dezembro de 1976, conforme alterada.

\footnotetext{
${ }^{3}$ Nos termos do artigo 56 da Instrução CVM 555, é de responsabilidade do administrador (i) calcular e divulgar o valor da cota e do patrimônio líquido do fundo aberto; disponibilizar aos cotistas extrato da conta do fundo; (iii) disponibilizar as informações do fundo, inclusive as relativas à composição da carteira, de forma equânime entre todos os cotistas; (iv) disponibilizar aos cotistas dos fundos não destinados exclusivamente a investidores qualificados a demonstração de desempenho do fundo até o último dia útil de fevereiro de cada ano; e (v) divulgar, em lugar de destaque na sua página na rede mundial de computadores e sem proteção de senha, a demonstração de desempenho do fundo.

4 "Art. 15. O sistema de distribuição de valores mobiliários compreende:

I - as instituições financeiras e demais sociedades que tenham por objeto distribuir emissão de valores mobiliários:

a) como agentes da companhia emissora;

b) por conta própria, subscrevendo ou comprando a emissão para a colocar no mercado;

II - as sociedades que tenham por objeto a compra de valores mobiliários em circulação no mercado, para os revender por conta própria;

III - as sociedades e os agentes autônomos que exerçam atividades de mediação na negociação de valores mobiliários, em bolsas de valores ou no mercado de balcão;

IV - as bolsas de valores;

$\mathrm{V}$ - entidades de mercado de balcão organizado;

VI - as corretoras de mercadorias, os operadores especiais e as Bolsas de Mercadorias e Futuros; e

VII - as entidades de compensação e liquidação de operações com valores mobiliários."
} 
Dada a sua responsabilidade perante a condução das atividades do fundo, o regulador optou por elencar, de forma taxativa, as obrigações do administrador, conforme constam do artigo 90 da Instrução CVM 555, dentre as quais, podem ser citadas, a título exemplificativo, as obrigações de custear a confecção do material de publicidade do fundo, atualizar e guardar livros e documentos relativos ao fundo, disponibilizar canal de atendimento aos cotistas e fiscalizar serviços prestados por terceiros ao fundo.

Sem prejuízo de tais deveres, devem, ainda, ser respeitadas pelo administrador determinadas normas de conduta, elencadas no artigo 92 da Instrução CVM 5555 , bem o dever de abster-se da prática de certos atos, conforme aduz o artigo $89^{6}$ da Instrução CVM 555.

\footnotetext{
5 “Art. 92. O administrador e o gestor, nas suas respectivas esferas de atuação, estão obrigados a adotar as seguintes normas de conduta:

I - exercer suas atividades buscando sempre as melhores condições para o fundo, empregando o cuidado e a diligência que todo homem ativo e probo costuma dispensar à administração de seus próprios negócios, atuando com lealdade em relação aos interesses dos cotistas e do fundo, evitando práticas que possam ferir a relação fiduciária com eles mantida, e respondendo por quaisquer infrações ou irregularidades que venham a ser cometidas sob sua administração ou gestão;

II - exercer, ou diligenciar para que sejam exercidos, todos os direitos decorrentes do patrimônio e das atividades do fundo, ressalvado o que dispuser o formulário de informações complementares sobre a política relativa ao exercício de direito de voto do fundo; e

III - empregar, na defesa dos direitos do cotista, a diligência exigida pelas circunstâncias, praticando todos os atos necessários para assegurá-los, e adotando as medidas judiciais cabíveis."

6 “Art. 89. É vedado ao administrador e ao gestor, no que aplicável, praticar os seguintes atos em nome do fundo:

I - receber depósito em conta corrente;

II - contrair ou efetuar empréstimos, salvo em modalidade autorizada pela CVM;

III - prestar fiança, aval, aceite ou coobrigar-se sob qualquer outra forma, ressalvada a hipótese prevista no art. 125, inciso V;

IV - vender cotas à prestação, sem prejuízo da integralização a prazo de cotas subscritas;

$\mathrm{V}$ - prometer rendimento predeterminado aos cotistas;

VI - realizar operações com ações fora de mercado organizado, ressalvadas as hipóteses de distribuições públicas, de exercício de direito de preferência e de conversão de debêntures em ações, exercício de bônus de subscrição, negociação de ações vinculadas a acordo de acionistas e nos casos em que a CVM tenha concedido prévia e expressa autorização;

VII - utilizar recursos do fundo para pagamento de seguro contra perdas financeiras de cotistas; e VIII - praticar qualquer ato de liberalidade."
} 
Tais medidas devem ser compreendidas como uma forma de garantir o correto funcionamento dos fundos, promover certa simetria de informações no e tutelar os interesses dos cotistas e de assegurar condições mais justas e equânimes de funcionamento do mercado de capitais brasileiro.

\subsubsection{Gestor}

O gestor do fundo de investimento é uma das figuras centrais na estrutura de funcionamento de um fundo de investimento, por ser o responsável pela tomada de decisão em relação à alocação de seus ativos para fins de investimento. Sua atuação, portanto, impacta diretamente na rentabilidade do fundo, devendo ser estratégica e estar em consonância com a política de investimentos do fundo.

Nos termos do artigo 78, parágrafo $3^{\circ}$, da Instrução CVM 555, não há obrigatoriedade legal de se contratar um gestor (que poderá ser pessoa jurídica ou natural), sendo certo que, nesta hipótese, a tarefa de alocar recursos e realizar investimentos será de responsabilidade do administrador.

Para atuar na gestão da carteira de um fundo, a pessoa ou entidade deverá estar legalmente habilitada para tanto perante a CVM e ser especializada na avaliação de cenários econômicos, acompanhamento de mercados e estruturação de carteiras de investimento, sendo prática recorrente no mercado que o gestor seja remunerado por meio do cálculo de uma taxa de performance (que varia de acordo com a rentabilidade do fundo).

A Instrução CVM 555 optou por auferir ao gestor um tratamento similar ao dispensado ao administrador, atribuindo-lhe as mesmas normas de condutas, prerrogativas e vedações que aquelas observadas por este, no que for aplicável. 


\subsubsection{Cotista}

Deve ser identificado como cotista o titular de, ao menos, uma cota de emissão do fundo. Tal cota é representativa de uma fração ideal da expressão econômica equivalente ao patrimônio do fundo.

Tecnicamente, a lei prevê que "as cotas do fundo correspondem a frações ideais de seu patrimônio, são escriturais, nominativas, e conferem iguais direitos e obrigações aos cotistas"7. Entretanto, há certos autores que emendam tal definição, em consonância com o que instrui Ricardo de Santos Freitas:

"Preferimos, no entanto, expressar que as cotas do fundo de investimento são valores mobiliários representativos da significação econômica de fração ideal do patrimônio comum. Isso porque o cotista não tem efetivo direito a uma parte ideal de cada bem que compõe o patrimônio do fundo, mas tão só à quantidade de moeda corrente nacional equivalente àquela parte ideal."

Embora ao detentor de cotas do fundo seja conferido o direito a um determinado quinhão, expresso em forma monetária, do que compõe seu patrimônio, uma importante característica da relação jurídica constituída entre o fundo e o cotista é a separação patrimonial. O patrimônio do fundo não pode ser afetado por dívidas e obrigações assumidas pelo cotista. Da mesma forma, o cotista não possui os direitos de utilização direta ou usufruto em relação aos bens e direitos que compõem a carteira do fundo.

Ademais, ao cotista não é dado o direito de administração do fundo, não sendo possível, portanto, influenciar a tomada de decisões na gestão direta da carteira do fundo (essa atribuição recai sobre instituição especializada, contratada especificamente para esse fim - vide item 1.4.2 acima). Não obstante, são-lhe outorgados poder de informação em relação às contas e negócios sob

\footnotetext{
${ }^{7}$ Artigo 11 da Instrução CVM 555.
} 
atuação do fundo, bem como poderes políticos em tal extensão que a vontade dos cotistas, expressa por meio de deliberação em assembleia geral, é soberana na estrutura administrativa do fundo, devendo ser acatada pelo administrador e por terceiros prestadores de outros serviços ao fundo, observadas as limitações e demais condições da Instrução CVM 555 e da regulamentação específica aplicável a cada espécie de fundo.

No regulamento do fundo poderão constar limites mínimos de aplicação de recursos, tanto em relação ao aporte inicial a ser realizado no momento de subscrição e integralização das cotas, quanto ao valor mínimo devido por cada cotista em razão da necessidade de aportes intercorrentes. Da mesma forma, pode ser exigido um valor mínimo de resgate, podendo, ainda, incidir taxa de saída. Sem embargo, o regulamento do fundo nunca poderá adotar tratamento diferenciado aos cotistas, valendo, portanto, todas as regras de aplicação e resgates das cotas de forma igual a todos os investidores no fundo.

Se, por um lado, é inegável a existência de relação contratual entre o cotista e o fundo (vide itens 1.2 e 1.3 acima), por outro, no que tange à existência de relação jurídica dos cotistas entre si, a doutrina se encontra dividida: há autores que afirmam não existir qualquer relação que associe os titulares de cotas de um fundo entre si, ao passo que outros defendem haver certa conexão, haja vista que seus direitos políticos, por exemplo, só são efetivados se atendido um critério de coletividade que lhes é essencial.

\subsubsection{Custodiante}

É recorrente que o administrador do fundo de investimento contrate instituição especializada para assumir a função de manter os ativos sob custódia em conta de depósito em nome do fundo, quando não obtiver autorização da 
CVM para a prestação de serviços de custódia. Especificamente em relação aos fundos sujeitos às disposições da Instrução CVM 555, a contratação de serviços de custódia é obrigatória, podendo o administrador exercê-los por conta própria (se legalmente habilitado para tanto) ou determinar que terceiro o faça.

Assim, nos termos do artigo 95, parágrafo $1^{\circ}$, da Instrução CVM 555:

" $\$ 1^{\circ}$ Somente podem compor a carteira do fundo ativos financeiros que sejam registrados em sistema de registro, objeto de custódia ou objeto de depósito central, em todos os casos junto a instituições devidamente autorizadas pelo Banco Central do Brasil ou pela CVM para desempenhar referidas atividades, nas suas respectivas áreas de competência."

O racional do regulador em relação a tal obrigatoriedade consiste na ideia de que, dessa forma, os ativos que compõem a carteira do fundo serão mantidos sob maior proteção, haja vista que a instituição custodiante se responsabiliza não apenas pela guarda dos mesmos, como também pela liquidação financeira de operações envolvendo tais ativos, devendo acatar ordens apenas do administrador e/ou gestor do fundo e de seus respectivos procuradores e mandatários.

Sem prejuízo da responsabilidade do custodiante, o administrador responde igualmente, em caráter solidário, por quaisquer danos ao fundo em decorrência da prestação do serviço de custódia, uma vez que a regulamentação atribui à instituição administradora a reponsabilidade por quaisquer atos por ela praticados em nome do fundo. Como a função de custódia é delegada pelo administrador, este também responde por eventuais condutas inidôneas por parte do custodiante. 


\subsubsection{Distribuidor}

As cotas do fundo de investimento só podem ser distribuídas no mercado por uma instituição integrante do sistema de distribuição de valores mobiliários. Se o administrador possua a autorização da CVM para atuar como distribuidor e faça parte de seu sistema de distribuição de valores mobiliários, poderá acumular essa função (da mesma forma que regula a norma em relação aos serviços de custodiante). Caso contrário ou no intuito de evitar o acúmulo de funções no fundo, o administrador poderá contratar instituição financeira que cumpra tal papel, mediante o pagamento de remuneração.

Há espécies de fundo cuja regulamentação específica permite a contratação de instituições intermediárias membros do sistema de distribuição de valores mobiliários. Nesse caso, é possível que o distribuidor subscreva ou adquira cotas por conta e ordem de seus respectivos investidores. A única diferença, portanto, reside no fato de que, dessa forma, os dados cadastrais com a identificação do investidor são mantidos junto ao distribuidor intermediário, não sendo repassados ao administrador do fundo, nos termos do artigo 30 da Instrução CVM 555, permanecendo tais cotas escrituradas em nome de daquela instituição.

\subsection{CLASSIFICAÇÃO}

O esforço de determinar critérios de classificação para os fundos de investimento ganhou maior significância em decorrência do intenso processo de estruturação e crescimento da indústria de fundos nas últimas décadas no Brasil. Tem-se por objetivo agrupar as mais diversas opções de carteira oferecidas no mercado de acordo com determinadas características do respectivo portfólio. 
Assim, levam-se em consideração as classes de ativos que compõem tal carteira, seus prazos e riscos, além dos estilos e estratégias de gestão.

Ao classificar os fundos em tipos ou categorias que expressam objetivos e políticas de investimento similares, busca-se alcançar um grau mais preciso de comparabilidade não apenas em relação aos fundos de investimento entre si, como também em um quadro comparativo de determinado fundo com outras opções de investimento. Dessa forma, é incontroversa a ideia de que uma classificação assertiva das diversas espécies e variações de fundos de investimento presentes no mercado só tem a auxiliar no processo de seleção e decisão de investimento, haja vista que facilita a identificação do fundo mais adequado ao perfil de cada investidor. Desta forma, a classificação permite a comparação mais eficaz entre fundos ou mesmo entre esses e outras opções de investimento.

Nesse sentido, recentemente as categorias de fundos de investimento reconhecidas no ordenamento brasileiro sofreram mudanças substanciais, por conta da edição da Instrução CVM 555. A nova norma passou a segregar os fundos de investimento em quatro novos grupos distintos, conforme listados em seu artigo 108, quais sejam, (i) os fundos de renda fixa (artigos 109 e ss.); (ii) os fundos de ações (artigo 115); (iii) os fundos cambiais (artigo 116); e (iv) os fundos multimercado (artigo 117).

No entendimento do regulador, o que define o enquadramento de cada fundo a tais quatro classificações é o fator de risco a que sua carteira está exposta. Dessa forma, são classificados como fundos "Renda Fixa" aqueles cujos recursos investidos, sempre em percentual de, no mínimo, 80\%, estão sujeitos aos riscos decorrentes de variações em taxas de juros, índices de preço, ou ambos. O artigo 112 da norma estabelece, ainda, que os fundos de renda fixa 
podem ser subclassificados como "referenciados" quando for superior a $95 \% \mathrm{o}$ percentual de alocação de recursos em ativos de renda fixa atrelados a um mesmo índice de referência, observadas as demais condições impostas pelo regulador no referido dispositivo ${ }^{8}$. Outras subclassificações para os fundos de renda fixa são a dos fundos "simples" e a dos fundos de "dívida externa", desde que atendam aos critérios dos artigos 113 e 114 da Instrução CVM 555, respectivamente.

Os fundos de ações, por sua vez, são caracterizados por assumir riscos relativos à variação de preços de ações admitidas à negociação no mercado organizado, ao passo que os fundos cambiais abarcam os riscos inerentes a investimentos realizados no mercado cambial, atrelados a variações de preços de moedas estrangeiras ou do cupom cambial.

Já o investidor que opta por adquirir cotas de um fundo classificado como multimercado, está disposto ter seu investimento sujeito a diversos fatores de risco distintos, haja vista que essa classificação de fundos não requer a concentração de seus recursos em um fator de risco específico. Não obstante, para todos os casos, exige-se que, na própria denominação do fundo de investimento, conste a classificação a que este pertence, devendo a expressão "Fundo de Investimento" ser complementada por "Renda Fixa", "de Ações", "Cambial" ou "Multimercado".

Há, ainda, os fundos de investimento estruturados, assim compreendidos os fundos que estão sujeitos à regulamentação específica emanada da CVM, cabendo a aplicação da Instrução CVM 555 apenas de forma subsidiária, no que os diplomas específicos forem omissos. São os principais fundos de

\footnotetext{
${ }^{8}$ Nesse caso, na denominação do fundo de investimento deverá constar o termo "Renda Fixa Referenciado" acompanhado da denominação ou sigla do índice de referência em questão.
} 
investimento estruturados: (i) os Fundos de Investimento Imobiliários (FII), regido pela Instrução da CVM no 472, de 31 de outubro de 2008, conforme alterada; (ii) os Fundos de Investimento em Direitos Creditórios (FIDIC), regido pela Instrução da CVM no 356, de 17 de dezembro de 2001, conforme alterada, e pela Instrução da CVM nº 444, de 08 de dezembro de 2006; (iii) Fundos de Investimento em Participações (FIP), regido pela Instrução da CVM n ${ }^{\circ}$ 391, de 16 de julho de 2003, conforme alterada; e (iv) Fundos Mútuos de Investimento em Empresas Emergentes (FMIEE), regido pela Instrução da CVM nº 209, de 25 de março de 1994, conforme alterada.

Sem prejuízo das classificações aqui apresentadas, pode-se dividir os fundos em abertos, fechados e exclusivos. Fundos exclusivos são aqueles que contam com apenas um cotista, detentor da totalidade de cotas de emissão do fundo em questão.

Já os fundos abertos, são aqueles em que é permitido que os investidores subscrevam e resgatem cotas a qualquer momento, variando, portanto, a todo momento o número total de cotas de emissão do fundo em circulação no mercado. Os fundos fechados, por sua vez, possuem uma quantidade fixa de cotas de sua emissão, havendo uma ou mais datas predefinidas para sua subscrição e/ou resgate. Outras importantes distinções entre esses dois tipos de fundo residem no fato de que o fundo fechado possui data já determinada para sua liquidação, ao passo que o fundo aberto pode ser constituído com prazo indeterminado, e de que a distribuição de cotas de um fundo fechado deve ser registrada junto à CVM, enquanto as cotas de emissão de um fundo aberto, para fins de distribuição, estão dispensadas de tal registro, nos termos dos artigos 18 e 20 da Instrução CVM 555. 
Para fins fiscais, os fundos devem, ainda, ser segregados em fundos de curto prazo e fundos de longo prazo, sendo certo que, neste caso, conforme a nomenclatura já indica, o prazo de duração do fundo, bem como a expectativa temporal de realização do investimento são os critérios levados em consideração quando observada tal classificação.

Por fim, vale comentar que a ANBIMA, no exercício de suas atribuições enquanto instituição autorreguladora do mercado de capitais brasileiro, definiu outros dois níveis de classificação para os fundos de investimento, a serem utilizados como referência adicionalmente à classificação geral instituída pela CVM por ocasião da edição da Instrução CVM 555. Assim, passa-se a contar com três níveis de classificação para os fundos de investimento.

Enquanto no Nível 1, há meramente uma noção básica do perfil do fundo, nestes segundo e terceiro níveis de classificação, nota-se uma maior especificação do estilo de gestão e da estratégia do fundo, cabendo à classificação de Nível 2 utilizar critérios quanto ao tipo de gestão e riscos, e à de Nível 3 se fazer de parâmetros quanto à estratégia de cada fundo. Dessa forma, em caráter exemplificativo, um fundo de renda fixa (de acordo com a classificação da CVM), pode ser subclassificado como "duração média" no Nível 2 da classificação da ANBIMA (evidenciando a orientação do gestor do fundo) e "grau de investimento" no Nível 3 (evidenciando uma estratégia de baixo risco para o segmento).

Diversas são, portanto, as formas e os critérios utilizados para classificar os fundos de investimento, o que torna ainda mais evidente seu caráter eclético, sendo nitidamente possível moldar sua estruturação de acordo com as necessidades e a estratégia dos operadores de mercado e, em última análise, do investidor. 


\section{CONTEXTUALIZAÇÃO SOCIOECONÔMICA E POLÍTICA}

Levando-se em consideração que se trata de um instituto pertencente à seara do direito comercial, seria falha a tentativa de revelar os atributos de um fundo de investimento de modo isolado das circunstâncias histórico-econômicas que motivaram seu surgimento.

Correta, portanto, é a premissa de que este estudo se esvazia sem uma prévia dimensão histórica das mudanças recentes na economia moderna e sua dialética com os planos político e social, tanto no Brasil, quanto ao redor do mundo. Por esse motivo, faz-se necessário ocupar-se, neste momento, de expor, com visão pragmática, os fatos responsáveis por reinventar os paradigmas do sistema capitalista contemporâneo, auferindo-lhe o formato tal como o conhecemos hoje, bem como compreender a cadeia de acontecimentos na história recente do Brasil e seus efeitos para o quadro sociopolítico e econômico do país.

\subsection{O SISTEMA CAPITALISTA MODERNO}

Primeiramente, cabe ponderar que o capitalismo consiste em um sistema econômico em constante transformação - transformação esta direcionada de acordo com fatores externos à economia em si, como, por exemplo, marcos sociais, políticos e culturais de uma determinada população, em um determinado território, durante um período de tempo específico. Apresentando-se como um mecanismo pulsante, de acordo com a disponibilidade de recursos escassos (oferta) e o seu emprego eficiente para atender a necessidades (demanda), o capitalismo experimentou diferentes fases ao longo da história da Humanidade. 
Nos primeiros esboços de organização civilizada do homem, seus esforços se concentravam exclusivamente na atividade agrícola, tendo o surgimento de uma nova tecnologia: a possibilidade de armazenamento de produção, alterado substancialmente o modelo capitalista praticado na época. Durante o período colonial, os pontos de foco do capitalismo eram a atividade mercantil e a concentração de metais preciosos, como o ouro. Com as inovações tecnológicas da Revolução Industrial, os fluxos de capital se deslocaram para os setores produtivos, inaugurando um novo momento para o capitalismo.

Nas últimas décadas, ao seu turno, modelos econômicos deixaram de ser impulsionados pelo capital mercantil ou pelo capital produtivo, passando a prevalecer o capital financeiro. A economia mundial opera atualmente de forma completamente dependente de relações comerciais sustentadas por operações financeiras, que se vem se tornando cada vez mais frequentes, interligadas e sofisticadas. O volume de operações financeiras a nível global cresceu vertiginosamente nos últimos anos, passando a envolver instituições bancárias, corretoras de investimento, agências de câmbio, companhias seguradoras, investidores em geral e, por vezes, até mesmo governos. Condensando tal ideia, são as palavras de Ricardo de Santos Freitas:

"Um dos principais fenômenos do sistema econômico mundial na história recente, parece-nos ser o marcante crescimento do volume de operações financeiros, bem como sua vertiginosa sofisticação. " (FREITAS, Ricardo dos Santos. 2005. p. 34)

E, ainda:

"Os ativos financeiros adquiriram tal importância que passaram a ser um valor de riqueza em si mesmos. Passaram a representar um nível muito superior à riqueza dos ativos reais, assim entendida como o conjunto de bens e serviços." (FREITAS, Ricardo dos Santos. 2005. p. 34) 
Tal fenômeno pode ser melhor compreendido a partir de uma projeção histórica de uma cadeia de eventos, sendo identificados pelos especialistas, preponderantemente, quatro macrofatores que foram fundamentais para que as organizações de investimento coletivo ganhassem a importância que possuem hoje.

Nesse sentido, o primeiro macrofator remete ao processo de internacionalização do mercado de câmbio (primeiro segmento do mercado financeiro a se tornar efetivamente global), como consequência ao fato de que os Estados Unidos optaram, no início da década de 1970, por desvincular o dólar do padrão ouro, na tentativa de conter o alto endividamento das contas públicas naquele momento. Com isso, uma operação de conversão de dólar para uma moeda estrangeira poderia ser feita diretamente, sem que antes fosse calculado o valor do dólar em ouro para, posteriormente, convertê-lo no equivalente em moeda estrangeira. Passou-se, dessa forma, a adotar taxas de câmbio flexíveis.

Adicionalmente, em 1979, os governos dos Estados Unidos e do Reino Unido deram início a um processo de diminuição (e, até mesmo, total abolição em certos casos) do controle alfandegário sobre movimentação de capitais em operações internacionais, tendo tal tendência sido acompanhada por diversos outros países industrializados e em processo de industrialização. Por conseguinte, um reflexo espontâneo de tal medida foi a maior liquidez ${ }^{9}$ auferida às transações internacionais, uma vez que o movimento de desregulamentação do mercado de câmbio internacional passou a oferecer mais vantagens e diversidade de escolhas a seus agentes.

\footnotetext{
${ }^{9}$ Entende-se liquidez como grau de facilidade para se converter bens em moeda.
} 
Outra forte consequência da estruturação de um mercado de câmbio internacional livre de amarras regulatórias foi um considerável acréscimo no volume de operações de emissão de bonds por diversos governos e empresas de grande porte. Na esfera pública, tal medida tinha por objetivo reduzir o elevado déficit orçamentário dos países industrializados naquele momento. Para a iniciativa privada, os recursos levantados com tais emissões financiavam o crescimento operacional de empresas que, cada vez mais, enfrentavam a necessidade de expandir sua produção a nível global.

Com a intensificação de operações de financiamento internacional por meio da emissão de valores mobiliários no mercado de capitais, tem-se o segundo macrofator determinante para o desenvolvimento do sistema capitalista contemporâneo, haja vista que foi inaugurada uma nova lógica de mercado do ponto de vista do investidor: quanto maior o nível de endividamento de uma organização, maior o risco assumido por quem a financiasse. Ato contínuo, o mercado passou naturalmente a relacionar o risco de um investimento ao seu retorno financeiro para o credor. Dessa forma, quanto maior o risco que o investidor estivesse disposto a correr, maiores os juros que ele esperaria receber do tomador do financiamento. Essa mudança se caracterizou como verdadeiro marco para o surgimento de um mercado sustentado por financiamentos com juros a longo prazo, operações de securitização ${ }^{10}$ e, por fim e em decorrência desses dois anteriores, de um mercado secundário, composto pela emissão e negociação de derivativos.

Em paralelo, um terceiro macrofator que contribuiu consideravelmente no aperfeiçoamento do capitalismo moderno foram as novidades tecnológicas que marcaram a segunda metade do século XX, em especial nos campos das

\footnotetext{
${ }^{10}$ Neste ponto, entende-se securitização como a operação de emissão de securities (valores mobiliários), representativos de um direito sobre ativo ou sua valorização.
} 
telecomunicações e informática. Com o boom da Internet e a massificação dos computadores, tornou-se muito mais simples e rápido processar as movimentações de recursos entre os mais diferentes mercados ao redor do planeta. Em outras palavras, as novas tecnologias foram responsáveis por gerar maior integração, segurança e agilidade no cotidiano do mercado financeiro internacional, quebrando barreiras geográficas e permitindo possibilidades infinitamente maiores para seus operadores.

Deve, por fim, ser citado como o último macrofator o fenômeno da desintermediação financeira, haja vista que os tomadores passaram a poder acessar investidores diretamente, sem a necessidade de instituições intermediárias, que passaram a figurar em operações de emissão de valores mobiliários, em muitos casos, como meros distribuidores de títulos no mercado. Tal alteração representou verdadeiro deslocamento do risco do agente intermediário diretamente para o investidor. Com efeito, ganharam ainda mais força as estruturas de investimento coletivo ${ }^{11}$, vez que, investindo coletivamente, os riscos de cada operação são mitigados se em relação ao mesmo investimento feito pelo investidor individualmente considerado.

\footnotetext{
11 Em 1974, foi promulgada, nos Estados Unidos, uma lei destinada a proteger as estruturas de concentração de recursos para programas de aposentadoria (Employee Retirement Income Security Act - Erisa), fazendo com que o volume de recursos dos fundos de pensão americanos atingisse a ordem de 667,7 bilhões de dólares já em 1980. Com a franca expansão desse setor, em 1993 o montante era de 3.571,4 bilhões de dólares. No Reino Unido, em 1980, os fundos de pensão totalizavam151,3 bilhões de dólares, representando 28\% de seu Produto Interno Bruto. Já em 1993, apenas 13 anos depois, os recursos controlados por fundos de pensão alcançavam, ao todo, 695,7 bilhões de dólares, ou seja, 73\% do Produto Interno Bruto britânico na época.

O mesmo ritmo de expansão vertiginosa pode ser percebido para os fundos de investimento, embora, nesse caso, o processo tenha ganhado maior impulso nas últimas três décadas. Seguindo a mesma base de comparação, estimou-se que, nos Estados Unidos, o volume de recursos dos mutual funds em 1980 era de 292,9 bilhões de dólares, tendo saltado para 2.011,3 bilhões de dólares em 1993. No Reino Unido os números são: 16,8 bilhões de dólares em 1980, contra 41,3 bilhões de dólares em 1993. Cfr. CHESNAIS, A mundialização financeira. Tradução de Carmem Cristina Caciacarro. 1. ed. São Paulo: Xamã VM Editora, 1998. p. 187 e 188, nota 8.
} 
Ademais, como uma estratégia do ponto de vista das finanças públicas, naquele momento diversos governos buscaram estipular a poupança interna, criando as condições legais e econômicas favoráveis para o surgimento de diversos fundos de investimento e de pensão.

Em suma, (i) a internalização do mercado de câmbio, seguida por (ii) o fortalecimento de um mercado de financiamento com juros a logo prazo, de valores mobiliários e de derivativos, acompanhados por (iii) avanços tecnológicos nas áreas da informática e das telecomunicações, e, por fim, (iv) o processo de desintermediação financeira, foram, dentre outros, os quatro principais fatores condicionantes que moldaram e definiram novas tendências para um sistema capitalista contemporâneo mormente dominado pelos fluxos intensos do mercado financeiro mundial.

\subsection{O ATUAL CENÁRIO ECONÔMICO-POLÍTICO MUNDIAL}

O mundo contemporâneo é marcado por uma nova realidade, tanto em aspectos sociais, quanto econômicos, políticos, tecnológicos e culturais. Como será apresentado nos itens subsequentes, a organização mundial foi redefinida a partir de um cenário político-econômico estruturado em razão de determinados acontecimentos históricos, quais sejam: (i) a consolidação do capitalismo como sistema socioeconômico global no contexto do pós-Guerra Fria; (ii) a intensificação das relações entre governos e grupos econômicos ao redor do mundo; (iii) avanços tecnológicos que facilitaram maiores fluxos de pessoas, mercadorias, informações e capitais; (iv) uma nova organização da atividade produtiva para atingir novos mercados; (v) o surgimento de superpotências emergentes e sua importância na tomada de decisões globais; (vi) a crise econômica dos mercados desenvolvidos, evidenciada a partir do colapso do 
mercado financeiro americano em 2008; e (vii) a desaceleração da economia da China e seus efeitos para os demais mercados.

Dada a interdependência e a alto grau de impacto de tais fatos entre si, sem a correta abordagem do assunto, não há como compreender as circunstâncias que levaram o mercado de capitais brasileiro a se desenvolver até chegar ao estágio em que se encontra atualmente, sendo, portanto, indispensável à compreensão do novo tratamento dado pelo regulador aos fundos de investimento no Brasil.

\subsubsection{O mundo multipolar e a insurgência dos mercados emergentes}

A nova organização da dinâmica político-econômica mundial, insurgente no período que sucedeu ao fim da Guerra Fria, não apenas consolidou o capitalismo como forma de organização socioeconômica em todas as regiões do planeta, como deu margem ao surgimento de novas potências em matéria econômica, política e militar. A título de ilustração desse atual paradigma, cabe a referência ao fato de que mundo ocidental voltou sua atenção para os mercados asiáticos e as democracias da América Latina se articularam de modo a adquirir maior relevância nas rodadas de discussões políticas globais.

Tais fatos devem ser compreendidos como efeitos atrelados a uma relação de causa que não pode ser explicada sem compreender a lógica organizacional da nova era capitalista vivida nos tempos atuais. Com os avanços tecnológicos em termos de informática e telecomunicações, somados ao fluxo mais intenso de pessoas, mercadorias e informações, as iniciativas empresariais encontraram as ferramentas e condições favoráveis para transpassar fronteiras nacionais e estruturar cadeias de produção e logística articuladas a nível global. Vive-se o momento das corporações maiores, em termos econômicos, até mesmo que 
países inteiros, com a presença de seus produtos e serviços nos mais diversos mercados e linhas de montagem geograficamente distribuídas de modo a otimizar custos e fomentar o padrão de produção on-demand, real-time.

O alto grau de cooperação entre governos e a intensificação das transações entre conglomerados econômicos globais propiciou que fossem relevadas novas potências no cenário político-econômico mundial. Em complemento a essa ideia, ocorreu também o crescimento do volume de operações internacionais e, consequentemente, um maior fluxo de recursos entre países, em decorrência de uma integração cada vez mais evidente dos principais mercados financeiros e de capitais no mundo. Dessa forma, os acontecimentos que afetam a bolsa de Tóquio hoje podem causar variações cambiais da moeda japonesa frente ao euro e, consequentemente, afetar o desempenho de empresas asiáticas listadas nas bolsas de Nova Iorque, o que poderia resvalar nos mercados de câmbio e de capitais brasileiros.

Esse aspecto ganha dimensão ainda mais significativa quando analisamos a recente tendência de agentes econômicos de países desenvolvidos destinarem parte de seus investimentos a mercados de países periféricos ${ }^{12}$. A esse novo grupo de países em desenvolvimento, que conquista cada vez mais a credibilidade internacional, vem apresentando bons índices de desempenho econômico e crescimento interno anual em taxas superiores às de economias desenvolvidas, foi alcunhado o termo de "países emergentes", tendo a comunidade econômica internacional reconhecido como seus principais players

\footnotetext{
${ }^{12}$ Em especial com a chegada da crise financeira americana em 2008, consolidou-se, em termos de fluxo de capitais e investimentos, ainda mais, essa tendência: diversas corporações adaptaram seus planos de expansão, realocando investimentos destinados aos mercados maduros, naquele momento em recessão, para oportunidades em países emergentes.
} 
o Brasil, a Rússia, a Índia, a China e, mais recentemente, a África do Sul, que juntos formaram os BRICS ${ }^{13}$.

No entanto, recentemente, a forte desaceleração da economia chinesa, mais acentuada do que o previsto, a crise econômica na Rússia, motivada pela queda do valor do barril de petróleo no mercado internacional, e as turbulências políticas e recessão econômica brasileiras, foram fatores que abalaram o prestígio internacional em relação aos BRICS, levando alguns teóricos a apontar a formação de um novo bloco de nações emergentes que poderão assumir posições de liderança global.

Tal bloco, apelidado de MINT, é formado por México, Indonésia, Nigéria e Turquia e possuem certos aspectos em comum com os BRICS: grandes mercados de consumo interno em franca expansão, massas populares em ascensão social, indicadores econômicos e de finanças públicas sob controle, inciativas de abertura de mercado, condições favoráveis para investimentos estrangeiros, mercados financeiro e de capitais mais adequados aos padrões internacionais de governança, dentre outros.

De toda sorte, indiferentemente dos rumos que tais nações (e outras) venham a levar no futuro, fato é que o centro de poder decisório global deixou de ser dividido por atores historicamente centrais nesse contexto, como os Estados Unidos, o Japão e as potências europeias. Dessa forma, já pode ser considerada uma realidade que o mundo não está mais sujeito a uma tomada concentrada de decisões, mas encontra-se atualmente organizado por meio de

\footnotetext{
${ }^{13}$ BRICS: sigla em inglês referente ao grupo político de cooperação internacional do qual fazem parte Brasil, Rússia, Índia, China e África do Sul. Os BRICS vêm ganhando maior hegemonia tanto política quanto econômica, tendo destaque, em relação ao último, a criação do Novo Banco de Desenvolvimento (em inglês, New Development Bank ou simplesmente NBD), que visa a fomentar e promover maiores garantias às relações comerciais de tais países participantes.
} 
diversos epicentros de influência político-econômica, distribuídos ao redor do globo, alterando de forma definitiva o funcionamento dos mercados internos de tais nações, incluindo o Brasil.

\subsection{O ATUAL CENÁRIO SOCIOECONÔMICO E POLÍTICO NO BRASIL}

Do ponto de vista social, nas últimas duas décadas, testemunhou-se mudanças significativas na estrutura social brasileira. Suportadas por avanços na área econômica, em especial no que tange à estabilização do câmbio e ao controle dos índices de inflação, tais alterações dão causa à nova realidade social vivida no país - ponto indispensável para dar a correta perspectiva à realidade econômica vivida no Brasil nos dias atuais.

Dentre os principais fatores que ocasionaram tais transformações, é correto destacar a elevação do poder de compra do brasileiro, a manutenção de um patamar de pleno emprego e a maior facilidade para obtenção de crédito e financiamentos, bem como o sucesso de programas sociais de distribuição de renda e de estímulo à oferta de crédito patrocinados pelo governo federal, como o Bolsa Família e o Minha Casa, Minha Vida, duas das principais propostas sociais do governo Lula.

No contexto econômico, desde o restabelecimento das eleições diretas, colocando fim ao regime militar, no final da década de 1980, o Brasil veio ganhando maior notoriedade internacional: as instituições políticas brasileiras se mostraram mais sólidas a partir da redemocratização, atraindo a confiança de investidores estrangeiros. Outro fator decisivo para compreender 0 desenvolvimento econômico brasileiro na história recente foi a criação e aplicação do Plano Real pelo governo do Presidente Itamar Franco, sob a supervisão do então Ministro da Fazenda Fernando Henrique Cardoso, que, em 
1994, deu novos rumos à economia brasileira, até aquele momento fadada ao insucesso de diversas investiduras estatais na tentativa de controlar a hiperinflação ${ }^{14}$ herdada do período militar e que ecoou durante os primeiros anos da "nova experiência democrática" no Brasil. Para dar a correta dimensão a esse período, vale o registro de Roberto Teixeira da Costa:

"As altíssimas taxas de inflação (beirando recentemente a hiperinflação) com que temos convivido nos últimos anos desvincularam totalmente o poupador de qualquer ideia de investimentos de médio prazo e muito menos de longo prazo. É sabido que um dos efeitos mais perversos da inflação é o encurtamento do horizonte temporal das aplicações. À medida que a inflação avança, os prazos de aplicação vão sendo cada vez menores, chegando a extremos como os agora verificados no caso brasileiro, em que uma parcela substancial de nossa poupança agregada gira a cada dia, praticamente remunerando a moeda à vista com taxas elevadíssimas que, evidentemente, só podem ser bancadas pelo próprio governo. Um complexo e bem fundamentado sistema financeiro criado desde meados da década de 1960 , tendo como base a lei do mercado de capitais, limita-se hoje a ser quase que exclusivamente um agenciador de títulos do governo."

(COSTA, Roberto Teixeira de. Crise, mercado de capitais $e$ capitalização de empresas in A modernização do capitalismo brasileiro: reforma do mercado de capitais. 1991. p. 6)

Basicamente tratava-se de um plano do governo federal com o objetivo de estabilizar a economia e realizar reformas estruturais ${ }^{15}$ em seu funcionamento. Em termos práticos, o Plano se dividiu em três etapas principais: adotou-se medidas de saneamento das finanças públicas, otimizando receitas e

\footnotetext{
${ }^{14}$ Conceito de hiperinflação:

15 Dentre as medidas mais significativas compreendidas no Plano Real, destacam-se: (i) políticas monetárias restritivas, que consistiam em um aumento da taxa básica de juros e do percentual de depósito compulsório dos bancos, visando a reduzir a oferta de crédito disponível aos brasileiros e aumentar a arrecadação de receitas do governo; (ii) abertura econômica, por meio da redução dos tributos incidentes sobre operações de importação e facilitação da prestação de serviços internacionais, como forma de amortecer eventuais excessos de demanda, que pressionava a inflação, promovendo uma gradual queda nos preços de produtos e serviços e estimulando o desenvolvimento da indústria nacional dada a maior exposição à concorrência internacional; (iii) contingenciamento, por meio da valorização artificial da moeda nacional, também estimulando o aumento das importações; (iv) equilíbrio fiscal, estabelecido graças a cortes de despesas e aumento de alíquotas de tributos federais; (v) privatizações, com o objetivo de exonerar o orçamento federal da necessidade de realizar investimentos que poderiam ser custeados, de forma mais eficiente, pela iniciativa privada - tratou-se de uma forma de o Estado obter receitas e atingir metas de superávit interno; e (vi) desindexação da economia, atrelando o ajuste de preços a um critério anual, de acordo com os custos de produção. Esta última medida foi especialmente importante, por ter interrompido o vício de corrigir valores com base na inflação passada em curtos períodos de tempo, o que agravava ainda mais o descontrole da inflação vivido naquele momento.
} 
realizando cortes de gastos e despesas na Administração Pública ${ }^{16}$. Ato contínuo, de modo a preservar o poder de compra do brasileiro durante o período de transição de moeda, instituiu-se a Unidade Real de Valor (URV) para que, então, pudesse ser posta em prática a terceira fase do Plano: o início da circulação do real como novo padrão monetário no Brasil. Gradualmente, percebeu-se que o sucesso do Plano era inegável, haja vista que, de fato, logrou pôr fim a um período traumático para a sociedade brasileira, registrado pelo completo descontrole em relação aos índices de preços nacionais.

Associado a uma política econômico-monetária mais estável e a taxas de juros básicos mais baixas, o apetite por consumo do mercado interno nacional amadureceu e ganhou maior robustez nas últimas décadas - em certa medida, o acesso de segmentos menos favorecidos da população brasileira a bens de consumo motivou diversas multinacionais a redirecionar suas estratégias de expansão para o Brasil, dentre outros mercados emergentes que demonstrassem grande potencial de consumo interno (vide item 2.2.1 acima).

Outro avanço fundamental para os rumos da economia brasileira decorrente de uma política monetária mais estável foi o aumento nos volumes de poupança registrados pelo período. Uma vez controlada a inflação, o brasileiro voltou a poder poupar dinheiro e investir. Esse ponto foi imprescindível para que o mercado de capitais nacional atingisse o estágio de desenvolvimento em que se encontra hoje, afinal, com o surto inflacionário anterior ao Plano Real estaria certamente fadado ao insucesso qualquer plano de fomento do mercado de capitais lançado pelo governo federal.

\footnotetext{
16 Havia, somente no âmbito federal, 100 autarquias, 40 fundações, 20 empresas públicas (sem considerar as empresas estatais), além de 2.000 cargos públicos com denominações imprecisas, atribuições mal definidas e remunerações díspares. Durante o governo de Fernando Henrique Cardoso, aproximadamente 20.000 funcionários foram demitidos do governo federal.
} 
Em razão de sua matriz de exportação fortemente atrelada a commodities, a economia brasileira apresentou altos níveis de crescimento durante mais de duas décadas (vide tabela abaixo), impulsionado, em grande parte, pelo vigor da plataforma econômica da China, voltada para a sustentação do crescimento a partir da demanda por aportes estatais em investimentos de infraestrutura, fazendo deste país um dos principais compradores, no cenário internacional, dos principais bens exportados pelo Brasil, quais sejam, os minérios de ferro e de cobre, a soja e o açúcar ${ }^{17}$.

\begin{tabular}{|c|c|}
\hline Ano & $\begin{array}{c}\text { Produto Interno Bruto (PIB) - } \\
\text { variação em volume }\end{array}$ \\
\hline 2010 & 7,8 \\
\hline 2009 & $-0,3$ \\
\hline 2008 & 5,2 \\
\hline 2007 & 6,1 \\
\hline 2006 & 4.0 \\
\hline 2005 & 3.2 \\
\hline 2004 & 5.7 \\
\hline 2003 & 1.1 \\
\hline 2002 & 2.7 \\
\hline 2001 & 1.3 \\
\hline 2000 & 4.3 \\
\hline 1999 & 0.3 \\
\hline 1998 & 0.0 \\
\hline 1997 & 3.4 \\
\hline 1996 & 2.2 \\
\hline 1995 & 4.2 \\
\hline 1994 & 5.8 \\
\hline 1993 & 4.9 \\
\hline 1992 & -0.5 \\
\hline 1991 & 1.0 \\
\hline 1990 & -4.3 \\
\hline
\end{tabular}

Tabela: Crescimento do Produto Interno Bruto (PIB) brasileiro de 1990 a 2010. ${ }^{18}$

Entretanto, em razão da desaceleração da economia chinesa, mais intensa do que esperado por especialistas, apesar de ainda considerada atualmente o

17 Fonte: http://g1.globo.com/economia/noticia/2014/01/china-foi-de-novo-principal-vendedor-ecomprador-do-brasil-em-2013.html

18 Fonte: Instituto Brasileiro de Geografia e Estatística - IBGE (http://www.ibge.gov.br/home/presidencia/noticias/imprensa/ppts/00000007765203112012522606619 383.xls) 
principal motor do crescimento econômico do mundo contemporâneo, muitos países em desenvolvimento (aqui destacam-se as nações latino-americanas, cujas balanças comerciais dependem diretamente do funcionamento dos mercados de commodities em condições favoráveis) entraram recentemente em uma grave recessão econômica. Neste grupo, e em razão de outros fatores econômicos internos, enquadra-se o Brasil.

Nesse sentido, cabe apontar que atualmente a atividade econômica brasileira se encontra em um quadro de recessão, sendo apontado por especialistas do mercado que a projeção do PIB para 2016 será de uma retração na ordem de $3,83 \%{ }^{19}$. Tal resultado pode ser explicado pela queda no volume total de investimentos estrangeiros no país, acompanhada de quedas na atividade industrial por anos consecutivos, aumento do nível de desemprego ${ }^{20}$, previsão da inflação no teto da meta do governo ${ }^{21}$, taxa SELIC em patamar histórico elevado $^{22}$ e prévia do déficit primário do governo federal em valores muito mais altos do que o esperado pelo mercado ${ }^{23}$.

Esse conjunto de dados macroeconômicos deve ser compreendido como um indicador de que a economia brasileira vem sofrendo o desgaste causado pelas diretrizes tomadas pela administração do governo de Dilma Rousseff ${ }^{24}$ na ordem econômica nacional. Em seu segundo mandato, a Presidente descumpriu o prometido durante sua campanha de reeleição, elevando as tarifas de energia

19 Fonte: http://www.istoedinheiro.com.br/noticias/economia/20160523/projecao-retracao-para-pib2016-passa-388-para-383-diz/375802

${ }^{20}$ Fonte: http://g1.globo.com/jornal-da-globo/noticia/2016/04/desemprego-no-brasil-chega-maior-taxada-serie-historica-do-ibge.html

21 Fonte: http://g1.globo.com/economia/mercados/noticia/2016/02/mercado-passa-prever-inflacao-nolimite-do-sistema-de-metas-para-2017.html

${ }^{22}$ Fonte: http://g1.globo.com/economia/noticia/2016/03/com-recessao-e-inflacao-alta-bc-deve-manterselic-em-1425-ao-ano.html

${ }^{23}$ Fonte: http://www.valor.com.br/politica/4576843/congresso-autoriza-deficit-primario-da-uniao-de-r1705-bilhoes

${ }^{24}$ Atualmente afastada da Presidência em razão da instauração de um processo de impeachment no Senado Federal. 
elétrica, o preço do combustível e a tributação em diversos setores da economia, medidas que apenas reforçaram ao mercado o caráter interventor de seu governo no plano econômico.

Não obstante as mais recentes turbulências na economia brasileira, deve ser corretamente apreciado o fato de que, nas últimas décadas, os mercados financeiro e de capitais brasileiros em muito se beneficiaram de importantes reformas regulamentares promovidas pelo governo federal. Adicionalmente, como forma de estímulo ao desenvolvimento do mercado de capitais, o governo promoveu incentivos fiscais, como a isenção de recolhimento do imposto de renda da pessoa jurídica (IRPJ) sobre os resultados de aplicações em fundos de investimento em participação (FIP).

Nesse mesmo passo, a abertura da economia brasileira em meados de 1990 resultou em uma maior atuação de investidores estrangeiros experientes no mercado nacional, influenciando tanto órgãos de regulação e autorregulação do mercado de capitais a editar normas de governança corporativa e boas práticas inspiradas no praticado nos mercados americano e europeu, quanto empresas e demais entidades de mercado a adotar tais padrões.

A diversificação de produtos e soluções financeiras também foi um marco desse período, assim como o aumento no volume ativos negociados em mercados de balcão organizado e bolsa ${ }^{25}$. $\mathrm{O}$ aumento na quantidade de operações de abertura de capital por meio de oferta pública de ações (em inglês, IPO, initial public offer) registradas na CVM até o ano de $2011^{26}$ também pode ser considerado um importante indício de que as medidas econômicas dos governos

\footnotetext{
${ }^{25}$ Fonte: http://www.valor.com.br/valor-investe/o-estrategista/3055586/mercado-de-capitais-brasileiroavancos-e-retrocessos

${ }^{26}$ Fonte: http://g1.globo.com/economia/mercados/noticia/2012/12/numero-de-empresas-que-entraramna-bovespa-caiu-73-em-2012.html
} 
passados e atual, não obstante erros e acertos ao longo do percurso, surtiram um impacto geral positivo e de inegável relevância na dinâmica e no desenvolvimento dos mercados financeiro e de capitais brasileiros. 


\section{O DESENVOLVIMENTO HISTÓRICO DOS FUNDOS DE INVESTIMENTO}

Não somente no Brasil, como em outros ordenamentos jurídicos, a figura do fundo de investimento (em seu sentido amplo) assumiu, ao longo da História, diferentes formas jurídicas, sujeitas aos mais contrastantes tratamentos legais. Com efeito, o sucesso do estudo que aqui se pretende traçar está sujeito a uma análise comparativa dos diferentes percursos seguidos por determinados países em relação ao desenvolvimento de seus respectivos veículos de investimento.

Como será evidenciado nos itens a seguir, juristas da Bélgica, Holanda, França, Inglaterra e Estados Unidos da America, por vezes no desafio de acompanhar os impulsos do mercado por novas estruturas, encontraram diferentes soluções para atender à necessidade de reunir capital para investimento de forma segura e eficiente do ponto de vista jurídico.

\subsection{NA EUROPA}

Os juristas internacionais dedicados ao assunto ainda não atingiram um consenso quanto ao exato momento em que foi constituído o primeiro fundo de investimento na história da Humanidade. Isto porque alguns estudiosos acenam que tal momento se deu a partir do surgimento de algumas estruturas jurídicas embrionárias na Grécia Antiga e no Império Romano ${ }^{27}$.

\footnotetext{
${ }^{27}$ O teórico Willian Carter, em seu artigo publicado na "Harvard Business Review" do ano de 1949, leciona que "the idea of pooling money for common investment in business under continuous supervision is not new: it flourished centuries ago in Greece, in Rome and Genoa. The first formal investment company was not organized, however, until a little over 100 years ago. This was the Société Génerale." Cfr. CARTER, W. D. Mutual Investment Funds. Harvard Business Review. New York, XXVII, n. 6, p. 717, nov. 1949.

Na mesma linha, ao tratar do histórico do fideicomisso e do trust, em sua monografia comparativa de ambos institutos, Antonio Stempel Paris afirma que “... se hace especialmente interesante dicho recuento histórico, a fin de hacer resaltar las profundas analogías existentes entre fideicomiso romano y el trust
} 
Muitos outros, ao seu turno, encontram o berço do fundo de investimento no surgimento dos investment trusts, no século XVIII, tendo o sistema financeiro da Bélgica sido o pioneiro ao desenvolver essa forma de veículo de investimento coletivo.

Não obstante tais divergências, para a correta compreensão e análise do instituto em questão, faz-se necessário traçar um breve panorama sobre eventos históricos que foram cruciais na evolução do conceito de fundo de investimento na Europa, processo que influenciou fortemente a moldagem do instituto até que se alcançasse as estruturas complexas e sofisticadas da atualidade.

De acordo com K. Geert Rouwenhorst, que, em sua obra "The Origin of Value", aborda com precisão o processo histórico de gênese dos fundos de investimento nas principais economias globais, houve duas modalidades de contrato anteriores influenciaram fortemente os fundos de investimento com suas peculiaridades tal como conhecidos hoje. Em ambas as formas de contrato, tem-se como característica comum o fato de se traduzirem em produtos de investimento coletivo.

O primeiro consiste em uma antiga variável de seguro de vida, que, não obstante tenha sido bastante popular nos séculos passados, atualmente se encontra totalmente em desuso: a tontina. A primeira tontina foi emitida na França, em 1653, por Lorenzo di Tonti ${ }^{28}$. Ao adquirir esse título, o investidor poderia contar com o pagamento de uma anuidade pela seguradora-emissora (o

anglosajón; hasta el extremo de que algunos autores muy respetables han considerado al trust (diez siglos más joven que el fideicomiso de Roma) como inspirado directamente en la anciana instituición latina. Sea ello o no certo, es um hecho palpable de su notoria similitud esencial." Cfr. PARIS, A. S. Trust y Fideicomiso. Collección de estudios jurídicos. v. VI. Caracas: Universidad Central de Venezuela, Facultad de Derecho, Sección de Publicaciones, 1955.

${ }^{28}$ Alguns teóricos defendem que, na realidade, a primeira tontina foi emitida em 1670, na Holanda, haja vista que a tontina de Lorenzo di Tonti, quando submetida para aprovação, foi rejeitada pela autoridade real francesa. 
que se assemelha aos juros de um empréstimo). $\mathrm{O}$ valor correspondente a tal anuidade aumentava caso algum de seus detentores viesse a falecer, reduzindose, assim, a quantidade de tontinas dispersas no mercado. Em um esforço de comparação, assemelhava-se rusticamente a um fundo de investimento no qual os cotistas recebiam juros periódicos que aumentavam conforme diminuía o número de cotistas.

A tontina era emitida com a finalidade de financiar um empreendimento e tal iniciativa deveria, ao longo do tempo, gerar os rendimentos que seriam utilizados para pagar a anuidade de seus titulares, em um fluxo de pagamentos próximo do que se observa nos fundos de investimento imobiliários nos dias atuais.

O autor denota, no entanto, que havia nítidas diferenças entre a tontina e um fundo de investimento, principalmente no que tange à sua finalidade: a tontina tinha por escopo auferir renda a seu titular, ao passo que a participação em um fundo de investimento envolve, além desse interesse, a busca por diversificação e liquidez. Afinal, a transferência de titularidade de uma tontina era concebida em situações excepcionalíssimas, não havendo, portanto, a fluidez que se percebe na negociação de cotas de fundos de investimento nos mercados atuais.

Nesse mesmo sentido, Rouwenhorst apresenta os empréstimos de plantação (hipotecas securitizadas de plantadores nas Índias Ocidentais) como o segundo mecanismo de investimento que pode ser considerado um precursor dos fundos. Uma vez agrupadas em lotes, tais hipotecas poderiam ser transformadas em ativos e, posteriormente, vendidas em conjunto para os investidores. Nesta hipótese, o instrumento em questão também se afastava do conceito moderno de fundo de investimento por nele se ausentar o critério da diversificação, visto que 
o risco de investidor estava necessariamente atrelado tão somente à dinâmica do mercado agrário.

Ainda segundo esse teórico, a primeira aparição de uma entidade de mercado com características próximas às dos fundos de investimento atuais tem registro em 1774, quando um corretor holandês chamado Abraham van Ketwich ofereceu a investidores a oportunidade de subscrever cotas de um consórcio intitulado Eendragt Maakt Magt (Unidade Faz a Força, em holandês).

A empreitada tinha por objetivo adquirir títulos de governos estrangeiros e também empréstimos de plantação ${ }^{29}$, assegurando o pagamento de dividendos anuais estipulados em 4\%, acrescidos de remuneração efetiva dependendo do desempenho dos ativos investidos. A entidade era o que se classifica hoje como um fundo fechado, com 2.000 ações/ $\operatorname{cotas}^{30}$ emitidas e negociadas na bolsa de valores de Amsterdã. Após sua distribuição, só seria possível adquirir as ações/cotas comprando-as de outros titulares (sendo vedado ao fundo emitir mais ações/cotas).

O Eendragt Maakt Magt possuía prospecto (da mesma forma que os fundos modernos), que se prestava, basicamente, a definir em quais ativos o fundo deveria investir e estabelecer obrigações relativas a prestação de contas. A remuneração do administrador (cujo papel era exercido pelo próprio Ketwich) era de $0,5 \%$ dos ativos quando do aporte (uma espécie de taxa de entrada),

\footnotetext{
${ }^{29}$ Os investimentos eram feitos em títulos (bonds) emitidos pelos governos da Áustria, da Dinamarca, de Estados independentes germânicos (que viriam a compor, posteriormente a Alemanha unificada), da Espanha, da Suécia e da Rússia, assim como em empréstimos de plantação de diversas colônias de exploração nas Américas Central e do Sul, caracterizando-o como um fundo de investimento em títulos estrangeiros.

${ }^{30}$ Em diversas obras, é utilizado o termo em inglês "share" para designar o título representativo da fração correspondente à participação de cada titular no capital do Eendragt Maakt Magt.
} 
acrescido de 100 gulden (moeda holandesa da época) ao ano para cada "classe" de ação/cota.

As ações/cotas podiam ser separadas em 20 diferentes "classes", que deveriam ser investidas em carteiras de cinquenta bônus. Cada classe possuía de 20 a 25 tipos distintos de ativo e não poderia acumular mais do que três unidades de determinado tipo de ativo, sendo, ainda, necessário manter sempre a proporcionalidade dos montantes aplicados. Nesse aspecto, pode-se traçar um paralelo entre essa peculiaridade e os limites de concentração observados nos fundos de investimento atuais, conforme contidos nos prospectos e definidos pela regulamentação aplicável (atualmente, a Instrução CVM 555, norma que substitui a Instrução CVM 409 - vide Capítulo 4 abaixo).

Sob o ponto de vista mercadológico, o Eendragt Maakt Magt representa uma verdadeira inovação ao representar uma maneira inusitada de oferecer diversificação para os pequenos investidores que não poderiam aplicar suas economias em diversos ativos diferentes.

Por outro lado, uma parte considerável dos autores especialistas neste assunto aponta que, na realidade, os fundos de investimento tiveram sua criação em um momento posterior: no bojo do surgimento do investment trust, que se deu em 18 de agosto de 1822, em Bruxelas. Naquela data, por determinação do Rei Guilherme de Orange da Bélgica, foi criada uma entidade de investimento coletivo sob a denominação de Allgemeene Nederlandche Maatsschappij ter Begungstigung van der Volsveit, com o intuito de financiar a agricultura local. Posteriormente, com a separação de Bélgica e Holanda, seu nome foi alterado 
para Société Génerale des Pays Bas e assim ficou conhecido o precursor dos investment trust. ${ }^{31}$

Sem ofuscar a importância da Bélgica e da Holanda enquanto palco dos acontecimentos históricos descritos acima, a Inglaterra é igualmente considerada por alguns autores como um dos principais “berços dos fundos de investimento". Suas leis revolucionaram o pensamento jurídico no decorrer do século XVI em razão da necessidade de desenvolver estruturas societárias que atendessem às demandas por investimento impulsionadas pelo otimismo das Grandes Navegações. Dessa forma, ainda que indiretamente, o país também contribuiu, em matéria legislativa, para o desenvolvimento de estruturas de investimento em geral.

Na realidade, a dinâmica do mercado de capitais inglês historicamente pendulou entre a adoção de formas societárias e da figura do trust como solução para canalizar investimentos coletivos, tendências estas geralmente determinadas em resposta às experiências vividas pelo mercado ao longo do tempo e às diferentes composições regulamentares que vigoraram em momentos distintos no período que se estende, aproximadamente, das décadas de 1720 a1980.

De qualquer forma, resta evidente o fato de que, na Inglaterra, pouco a pouco, deixou-se de utilizar estruturas societárias (e.g. sociedades limitadas e companhias) como principal instrumento de concentração de recursos de uma pluralidade de investidores e acesso ao mercado financeiro para dar lugar aos

\footnotetext{
${ }^{31}$ Alguns teóricos resistem a essa teoria sob o argumento de que a Société Génerale des Pays Bas não continha todas as características de um investment trust. Nas palavras de Ricardo de Santos Freitas: "ocorre que a Société Génerale des Pays Bas era uma estrutura que não reconhecia o princípio da divisão de riscos, propondo-se apenas a facilitar o ingresso dos títulos estrangeiros no mercado nacional, razão pela qual alguns estudiosos entendem não ser legítimo apontá-la como precursora. ”
} 
trusts (principalmente em sua modalidade open-ended). Tal movimento ganhou maior intensidade após a promulgação do Financial Services Act, em 1986, determinando que todos os esquemas de investimento coletivo (collective investment schemes) só poderiam ser autorizados a funcionar caso se organizassem sob a forma de unit trust ${ }^{32}$.

Nas últimas décadas, contudo, em passo com o acelerado desenvolvimento tecnológico no setor das telecomunicações e informática, a dinâmica de funcionamento das operações financeiras a nível global mudou radicalmente, tornando o fluxo de capital mais célere e intenso. Observou-se, a partir de então, no mercado europeu, a consolidação das entidades (ou veículos) de investimento coletivo modernas ${ }^{33}$, que ampliaram o acesso ao mercado financeiro, principalmente em relação a pequenos investidores, haja vista que concentravam, de modo descomplicado, recursos de diversas pessoas em volume tal que se torna possível a realização de operações de maior complexidade, geralmente incompatíveis com o perfil de um pequeno investidor isolado.

Assim, em linhas gerais, pode-se compreender que a história que se debruça diante do surgimento dos fundos de investimento em seu sentido estrito (ou seja, tal como conhecidos na atualidade) está intimamente ligada e é diretamente influenciada pelos acontecimentos históricos que marcam a criação dos primeiros investment trusts na Europa a partir do século XVII, principalmente na Holanda, na Bélgica e na Inglaterra.

\footnotetext{
32 Situação análoga ocorreu no Brasil em razão da regulamentação emanada do Banco Central para o funcionamento dos fundos de investimento logo nos primeiros anos de adoção, pelo mercado, dessa solução jurídica (vide item

33 Neste contexto, na prática internacional, conforme reconhecido na Diretiva do Conselho da Comunidade Europeia $n^{\circ}$ 85/611, alterada pelas Diretivas $n^{\circ}$ 88/220/CEE, 95/26/CE, 2000/64/CE, 2001/107/CE e 2001/108/CE, tais estruturas de investimento coletivo podem ser encontradas nas seguintes modalidades: fundos de investimento, companhias de investimento e unit trusts.
} 


\subsection{NOS ESTADOS UNIDOS DA AMÉRICA}

Nos Estados Unidos, o conceito e o tratamento legal e regulamentar aplicável aos fundos de investimento só pode ser integralmente compreendido quando analisados, primeiramente, a noção e o desenvolvimento histórico do trust, figura de enorme popularidade nos países da Common Law que não encontra par no ordenamento brasileiro.

O termo trust (fideicomisso, na tradução mais aproximada para o português) remete à custódia e administração de bens de terceiros. Em regra, trata-se de qualquer tipo de negócio jurídico que consista na entrega de um bem a uma pessoa (fiduciário) para que seja administrado em favor do depositante ou de outra pessoa por ele indicada (beneficiário). Embora o fiduciário possua o título da propriedade do bem em questão, ele é obrigado legalmente a administrar a propriedade não para seu próprio benefício, mas em benefício de terceiro (no caso, o depositante ou pessoa por ele indicada).

Assim, no esforço de melhor compreender de que se trata o trust e como esta figura surgiu no direito norte-americano, deve-se regressar ao ano de 1823 , quando a primeira sociedade de investimentos de que se tem registro foi constituída sob a denominação de Massachussets Hospital Life Insurance Company. A empresa matinha acordos com seus clientes que se assemelhavam às relações de um common trust fund, em razão do vasto portfólio de apólices de seguro em que as pessoas poderiam "investir".

Com o passar de aproximadamente uma década, não houve avanços significativos na indústria de investimentos coletivos, o que se comprova pelo fato de que, no ano de 1921, existiam apenas 40 investment trusts em atividade nos Estados Unidos. Em 1926, no entanto, esse número saltou para 126, 
estimulado, principalmente, pelo vertiginoso crescimento da renda média da população americana na época. Três anos depois, alcançava-se a marca de 760 trusts em operação.

Com a queda da Bolsa de Nova York naquele mesmo ano de 1929, houve uma forte retração de investimentos no mercado financeiro, de modo que, em 1936, o número de investment trusts havia caído para 120. Em estudos desenvolvidos pela Securities \& Exchange Comission (SEC) com uma análise detalhada sobre os impactos da crise em relação aos investment trusts, identificou-se, como uma das principais causas para a queda, a composição altamente alavancada dos investimentos detidos por tais entidades.

Como reflexo natural à crise vivida na década de 1930 , nesse período entram em vigor alguns dos diplomas legais mais importantes em relação a esse tema. Em 1933, o governo promulga o Securities Act e, em 1934, o Securities Exchange Act. No ano de 1936, foi promulgado o Public Utility Holding Company Act e, por fim, em 1940, tem-se o Investment Company Act, tendo este último sido, em grande parte, responsável por reestabelecer a confiança do investidor e impulsionar fortemente o investimento em sociedades de investimento americanas, representando verdadeiro marco no desenvolvimento histórico deste segmento.

Ainda sobre o Investment Company Act, de 1940, o jurista Ricardo dos Santo Freitas faz pertinentes comentários às definições trazidas em sua Seção 4:

"A Seção 4 do Investment Company Act de 1940 estabelece uma classificação das estruturas em três categorias:

Face-amount certificate companies: desenvolvem sua atividade mediante a emissão de certificados de participação - definidos, por sua vez, no item (15) da Seção da mesma Lei - que, essencialmente, garantem o 
pagamento a seu titular de uma determinada soma de dinheiro em uma data fixa;

Unit investment trusts: são estruturas organizadas sob a forma de um common law trust que carecem de um órgão de administração e emitem unidades reembolsáveis (units), desprovidas de direito de voto, cada uma das quais representa uma cota indivisa de patrimônio fiduciário detido por um trustee.

Management companies: esta é a categoria principal e residual das estruturas de investimento, posto que compreende qualquer outra forma distinta das precedentes.

As management companies, por sua vez, em conformidade com a Seção 5, recebem duas classificações:

- 'sociedades de investimento abertas' (open-end companies) que oferecem a subscrição de ações resgatáveis emitidas por elas; e 'sociedades de investimento fechadas' (close-end companies), que oferecem ações não resgatáveis;

- 'sociedades diversificadas' (diversified companies), que têm, no mínimo, $75 \%$ do valor de seu patrimônio investido em ativos financeiros, valores públicos, valores de outras sociedades de investimento ou outro tipo de valores, sem que as aplicações em um mesmo emissor representem nem mais do que 5\% do valor do patrimônio total da sociedade, nem mais de $10 \%$ dos direitos de voto inerentes às ações daquele mesmo emissor; e 'sociedades não diversificadas' (non-diversified companies), que não se encaixam na definição anterior." (FREITAS, Ricardo dos Santos. 2005. p. 73)

Pode-se perceber, portanto, que, nos Estados Unidos, há diversas espécies de entidades de investimento coletivo que podem assumir o papel equivalente ao de um fundo de investimento para o sistema brasileiro, sendo um exemplo o fato de o conceito de mutual fund, tão recorrente no mercado financeiro norte-americano, consistir em uma investment company, com ações resgatáveis, que investe em uma carteira de securities. Além disso, o fato de as diversified companies americanas só estarem autorizadas a realizar investimentos dentro de determinados limites de concentração aproxima essa categoria dos fundos de investimento regidos pela lei brasileira.

\subsection{NO BRASIL}

No Brasil, diferentemente de como ocorreu em outros sistemas (vide itens 3.1 e 3.2 acima), os fundos de investimento, constituídos sob a forma de condomínio, surgiram por volta da década de 1960 como uma solução tardia ao 
fato de que nenhum dos tipos societários existentes no ordenamento pátrio atendia de forma satisfatória às necessidades dos investidores em sua intenção de concentrar e organizar recursos financeiros para aplicação em ativos visando à obtenção de rendimentos.

Dessa forma, cabe, neste momento, analisar sumariamente o contexto histórico-econômico que permitiu o desenvolvimento do instituto jurídico que aqui se desafia examinar até que lhe fosse auferido efetivamente o tratamento jurídico atual.

Nesse sentido, embora ainda seja um ponto controverso, a doutrina prevalecente aponta que a origem dos fundos de investimento no Brasil tenha se dado a partir das figuras da sociedade de investimentos e da sociedade em conta de participação, haja vista que a primeira forma jurídica adotada no mercado brasileiro para a concentração de recursos com a finalidade exclusiva de investimento foi a forma societária. Assim, o esforço de compreender a evolução dos fundos de investimento requer, em primeira análise, um estudo mais atento às variações legislativas incidentes sobre as sociedades de investimento e em conta de participação.

As primeiras sociedades de investimento surgiram ao longo da década de 1940, durante a $2^{\text {a }}$ Guerra Mundial, porém com atuação ainda tímida, haja vista que as próprias circunstâncias da guerra inibiam, de certa forma, a demanda por investimentos diversificados. Com o fim dos conflitos, no entanto, o setor sofreu forte crescimento, atingindo, em 1953, o total de 54 sociedades de investimento ${ }^{34} \mathrm{em}$ atividade no Brasil.

\footnotetext{
${ }^{34}$ Bernardo Pajiste registra: "o fato é que hoje estão inscritas na Superintendência da Moeda e do Crédito 67 companhias, que têm o nome de sociedade de investimento. Entre estas companhias, existem 7 entidades que se dedicam exclusivamente à corretagem de seguros ou financiamento imobiliário, loteamento de terras, exploração de hotéis, cinemas, etc. e que, na realidade, não possuem nenhum
} 
Deve-se atentar para o fato de que tais sociedades de investimento, embora tivessem sócios e fossem constituídas nos termos de um estatuto social, contavam, ainda, com documento adicional, a que cabia definir as regras aplicáveis à relação entre a sociedade e as pessoas que decidissem aportar recursos em seu fundo visando ao rendimento de tal aplicação, tal como se um contrato fosse. A esse documento era dado o nome de regulamento e seu teor consistia em estabelecer os termos e condições da concentração de investimentos de terceiros na sociedade de investimento, constituindo seu fundo ${ }^{35}$.

Dessa forma, percebe-se que, naquele tempo, o conceito de fundo nada mais era que a denominação dada aos recursos obtidos com terceiros e injetados em uma sociedade de investimento para que seus sócios realizassem aplicações, com vistas ao rendimento do capital de tais investidores. Até que, em 1957, em resposta à nova regulamentação do setor (vide item 3.3.1 abaixo), surgiu o Fundo Crescinco, o primeiro fundo de investimentos no Brasil constituído sob a forma de condomínio, abandonando de vez a forma societária para a organização de tal veículo de investimentos.

A relevância dessa mudança é notória, como bem esclarece Ricardo de Santos Freitas:

"A inovação trazida pelo fundo Crescinco foi marcante. Rompe-se um padrão de comportamento no uso de formas negociais. Não há aporte de

\footnotetext{
elemento, para justificar sua denominação, a não ser a palavra 'investimento', utilizada para aumentar a confusão. Um outro grupo, de 6 companhias, se ocupa, quase exclusivamente, de negócios imobiliários e não pode ser também considerado na categoria das sociedades, que nos interessam. Em resumo, e segundo a melhor estatística, há no Brasil, ao todo, 54 companhias de investimento."

35 "Estes (os sócios), para contratar com investidores a captação de recursos para geri-los em conjunto com os recursos de outros investidores, elaboravam um documento, intitulado regulamento, de algo intitulado fundo, que era o contrato a reger a relação entre as partes." (FREITAS, Ricardo dos Santos. 2005. p. 85)
} 
capitais em uma sociedade de investimentos, nem em uma sociedade em conta de participação em que a sociedade de investimentos seja sócia ostensiva. Pura e simplesmente institui-se, por escritura pública, um condomínio, nos termos da legislação civil, regido por um regulamento que define minuciosamente o modo de organização e funcionamento dessa nova estrutura (...).” (FREITAS, Ricardo dos Santos. 2005. p. 86)

Desse modo, apesar de a estrutura organizacional de diversas instituições financeiras da época, que buscavam angariar recursos de investidores para aplicação, não se coadunar com a forma condominial, havendo, portanto, resistência ao novo conceito de fundo de investimento, manter investimentos em uma sociedade de investimentos ou em conta de participação representaria desvantagens significativas: os ganhos financeiros eram tributados duas vezes até chegar ao investidor final ${ }^{36}$. Além disso, a sociedade, para funcionar, pressupõe a existência de um capital social fixo, o que comprometia a estrutura em termos de liquidez.

De toda forma, uma vez constituídos os primeiros fundos de investimento sob o regime jurídico de condomínio, viu-se a necessidade de determinar qual seria o tratamento fiscal dispensado a tais entidades. Nesse contexto, foi promulgada a Lei $\mathrm{n}^{\mathrm{o}} 3.470$, de 28 de novembro de 1958 , que ratificou não ser o fundo de investimento considerado uma pessoa jurídica, para fins de tributação do imposto de renda, desde que, observadas outras condições, fosse constituído

\footnotetext{
${ }^{36}$ Oportuna foi a ressalva de Ricardo de Santos Freitas: "a verdade é que o problema da dupla tributação quanto às sociedades de investimento já deveria ser considerado como eliminado desde 1955, por disposição do art. 43 do Regulamento do Imposto de Renda à época vigente, o Decreto 36.773, de 13 de janeiro. Mas o texto do artigo tinha redação genérica prevendo a exclusão do lucro real para efeitos da tributação dos 'lucros e dividendos que já houverem sofrido a taxação proporcional em poder das sociedades que s distribuíram, desde que se prove pagamento'. A generalidade da norma gerava insegurança e dúvidas de interpretação às sociedades de investimento." (FREITAS, Ricardo dos Santos. 2005. p. 86)
} 
sob a forma condominial e administrado por sociedade de investimentos fiscalizada pela Superintendência da Moeda e do Crédito ${ }^{37}$.

Houve, ainda, em momentos posteriores, esforços legislativos no sentido de introduzir novas estruturas jurídicas como solução para crescente demanda por veículos de investimento coletivo, tal como ocorreu ao ser promulgada a Lei $\mathrm{n}^{\text {o }} 4.728$, de 14 de julho de 1965, que criou as sociedades anônimas de capital autorizado $^{38}$. Em outras ocasiões, o legislador aproveitou para estipular regras mais rígidas em relação à administração e o funcionamento dos fundos de investimento $^{39}$, na tentativa de aproximar, em termos práticos, a atuação dos fundos do conceito de sociedade anônima de capital autorizado até que aqueles fossem convertidos nesta.

Sem embargo, os benefícios fiscais concedidos a investidores de fundos naquela época foram um dos fatores que hoje devem ser mencionados para explicar porque os fundos de investimento se tornaram cada vez mais populares e as sociedades de capital autorizado, por sua vez, não conquistaram a simpatia do mercado. Além disso, o Banco Central, considerando sua preocupação com a exposição excessiva das sociedades do setor financeiro aos riscos decorrentes de maus investimentos eventualmente realizados com recursos de terceiros e os danos causados ao mercado com a falência de tais instituições, tomou rumo

\footnotetext{
37 Autarquia federal anteriormente responsável pelas funções de definição de taxa básica de juros, controle de taxas de câmbio, regulação e fiscalização do sistema financeiro nacional, dentre outras - foi extinta em razão da criação do Banco Central do Brasil em 1965.

${ }^{38}$ A ideia por trás da criação das sociedades anônimas de capital autorizado era a de permitir que uma sociedade se constituísse mediante subscrição e integralização de ações em valor inferior ao estipulado no estatuto social, na tentativa de solucionar um dos principais pontos negativos da utilização da via societária como forma de canalizar recursos para investir coletivamente, qual seja, a necessidade de manter aportado o capital social, de forma fixa, enquanto forem mantidas as atividades da sociedade.

${ }^{39}$ A Lei $\mathrm{n}^{\circ} 4.728 / 65$, por exemplo, previu, ainda, que os fundos em condomínio destinados à aplicação em títulos e valores mobiliários deveriam ter sua carteira administrada por uma companhia de investimentos e suas contas auditadas por empresa de auditoria independente devidamente registrada no Banco Central do Brasil. Ademais, foi instituída a obrigação de realizar assembleia geral anual de cotistas para deliberar em relação à prestação de contas do fundo e ao balanço patrimonial apresentado pela instituição administradora.
} 
contrário ao das orientações emanadas do Legislativo e regulamentou definitivamente essa nova figura no ordenamento brasileiro. Nasce, então, a partir da edição da Resolução n ${ }^{\circ}$ 145, de 14 de abril de 1970, o conceito moderno de fundo de investimento, cujas principais características, figuras envolvidas e classificações, dentre outros pontos, serão melhor evidenciados a seguir.

\subsubsection{Histórico regulatório}

Conforme evidenciado anteriormente, o conceito de fundo no Brasil encontra sua gênese no bojo das sociedades de investimento e em conta de participação. Por essa razão, o esforço de traçar uma linha do tempo regulatória para os fundos de investimento requer, em primeira análise, uma compreensão mais cuidadosa de como surgiram, do ponto de vista legal, tais sociedades.

A primeira menção em lei a tais tipos societários, portanto, deu-se por via do Decreto-lei n. 7.583, promulgado em 25 de maio de 1945, reconhecendo a existência, dentre outras ${ }^{40}$, das sociedades de investimento, e atribuindo competência legislativa ao Ministério da Fazenda para que definisse o regramento aplicável a tais tipos societários até então inéditos, do ponto de vista legal, no ordenamento pátrio. Vale comentar que, naquele momento, já era utilizado o termo "fundo", porém com significado tecnicamente diverso do que se conhece hoje: empregava-se a palavra para identificar a parcela do patrimônio dos sócios aportada na sociedade destinada exclusivamente à realização de investimentos.

\footnotetext{
${ }^{40}$ É a redação do artigo $1^{\circ}$ do Decreto-lei $n^{\circ} 7.583$, de 25 de maio de 1945 : “Art. $1^{\circ}$ Não gozam das prerrogativas e vantagens previstas na legislação referente à Caixa de Mobilização e Fiscalização Bancária, nem se subordinam às disposições dos artigos $5^{\circ}$ e $6^{\circ}$ do Decreto-lei $n^{\circ} 6.419$, de 13 de abril de 1944, alterado pelo Decreto-lei ${ }^{\circ}$ 6. 541, de 29 de maio de 1944, as sociedades de crédito, financiamento ou investimentos, desde que não recebam depósitos." (grifei)
} 
Em 1946, refletindo a nova realidade que se vivia no Brasil a partir do fim da $2^{\text {a }}$ Guerra Mundial e da Era Vargas, promulgou-se nova Constituição, que determinava ser de exclusividade da União a competência para legislar sobre normas de Direito Financeiro, além de atribuir-lhe autoridade para fiscalizar as operações de crédito, capitalização e seguros. Passou-se, a partir de então, por um hiato regulatório que se prolongou até 1959, quando o Ministério da Fazenda editou a Portaria $\mathrm{n}^{\mathbf{0}} 309$, de 30 de novembro daquele ano. Tal normativo foi responsável por alterar substancialmente o papel das sociedades de investimento, crédito e financiamento, sob a justificativa de que, dada a sua importância para o desenvolvimento da economia nacional, seria imprescindível estabelecer regras que distinguissem sua atuação das funções exercidas por bancos e demais instituições financeiras.

Finalmente, em 10 de dezembro de 1968, passa a vigorar a Resolução $n^{\circ}$ 103, do Banco Central do Brasil, em atendimento a deliberação emanada do Conselho Monetário Nacional, cujo inciso IV foi apresentado com a seguinte redação:

"IV - Vedar às sociedades de crédito, financiamento e às de tipo misto a constituição, administração ou gerência de FUNDOS MÚTUOS DE FINANCIAMENTO, ou FUNDOS DE "ACCEPTANCE", e, ainda, a partir desta data, a colocação de novas cotas de Fundos que funcionem sob o regime de sociedade em conta de participação, condomínio ou quaisquer outras formas, assim entendido, para os efeitos deste item, "uma comunhão de recursos destinados à aplicação em operações de crédito, com base em papéis comerciais" (Circular n ${ }^{\circ} 72$, de 30.11.1962, da extinta SUMOC)." (grifei)

Em termos de desdobramentos históricos do desenvolvimento dos fundos de investimento no Brasil, essa norma possui significância ímpar, haja vista que pôs fím ao conceito de "fundo" enquanto o conjunto de recursos aportados em uma sociedade de financiamento ou em conta de participação para fins de investimento. Adicionalmente, a letra da lei foi clara no sentido de auferir aos fundos, pela primeira vez, uma identidade própria e, inclusive, liberdade de 
forma, permitindo, portanto, que estes adotassem contorno jurídico mais expressivo do que o de mero atributo intrínseco a determinadas sociedades ${ }^{41}$, tal como eram classificados pela doutrina até então.

Por outro lado, a Resolução n 103 , embora inegável seu caráter inovador por extrair o conceito de fundo das estruturas societárias daquele momento, ao deixar em aberto sob qual forma jurídica essa nova figura deveria se constituir, causou receios e questionamentos aos agentes de mercado na época, até que, em 14 de abril de 1970, o Banco Central do Brasil editou a Resolução n ${ }^{\circ} 145$, dando origem à figura do fundo mútuo de investimento. Tem-se, então, o primeiro diploma normativo que trata do instituto a partir de uma estrutura jurídica similar à vigente nos dias atuais.

Nos termos da Resolução $\mathrm{n}^{\circ} 145$, o fundo deveria ser constituído sob a forma de condomínio, ter seus atos constitutivos arquivados no registro competente e obter inscrição própria no cadastro de contribuintes da Receita Federal do Brasil. Assim, o instituto passou a ser tratado a partir de uma formatação muito próxima da atual. Outra diferença significativa para a matéria advinda da nova regulamentação foi o fato de que o fundo seria diretamente de propriedade de seus cotistas, e não da instituição administradora ${ }^{42}$.

Em paralelo a tais mudanças, como uma forma adicional de incentivo à adoção dos fundos enquanto veículo para a realização de aportes de investimento, o governo federal passou a oferecer incentivos fiscais por meio de

\footnotetext{
${ }^{41}$ Mais do que dar "vida própria" aos fundos, a real preocupação do Banco Central, refletida naquela Resolução, era de proteger a atuação das sociedades que contavam com fundos para aplicação (e, consequentemente, a estabilidade da economia nacional), dado o risco de que más escolhas de investimento por tais instituições financeiras, quando em escala, acabassem por minar a dinâmica econômica do país.

42 Anteriormente, a sociedade (em conta de participação ou de financiamento) cumulava ambas as funções: era tanto administradora, quanto proprietária dos recursos, que, em conjunto, seriam considerados "fundo".
} 
programas, tal como o fundo $157^{43}$. Após tal medida, o governo federal ainda concedeu outros benefícios fiscais para esse tipo de estrutura nos anos seguintes, cabendo citar, a título exemplificativo, a criação do Fundo de Investimentos do Nordeste - FINOR, o Fundo de Investimentos da Amazônia - FISET, e o Fundo de Investimentos Setoriais - FISET, todos instituídos pelo Decreto-lei n ${ }^{\circ} 1.376$, de 12 de dezembro de $1974^{44}$.

Não obstante os importantes avanços no assunto ao longo das décadas de 1970 e 1980, pode-se afirmar que somente a partir da década de 1990 os fundos de investimento se desenvolveram e se popularizaram a ponto de movimentar uma verdadeira indústria financeira exclusivamente para este fim. Tal fato deve ser compreendido também como consequência natural do sucesso das medidas impostas pelo Plano Real: com a inflação controlada, política monetária sólida e mercados de câmbio estáveis, tinha-se um cenário econômico propício à realização de poupança e investimentos. Sem tais avanços, seria impossível estruturar um mercado de capitais nacional desenvolvido e que demonstrasse condições de atrair tanto investimentos nacionais e estrangeiros, quanto empresas brasileiras dispostas a acessar o mercado para financiar seus projetos.

\footnotetext{
${ }^{43}$ Como explica Ricardo de Santos Freitas: "o caso do chamado fundo 157é bem ilustrativo. Criado pelo Decreto-lei $\mathrm{n}^{\circ} 157$, de 10 de fevereiro de 1967, tratava-se de sistema de incentivo fiscal para estimular o desenvolvimento de empresas. Pessoas físicas e jurídicas podiam destinar 10\% do imposto de renda a pagar para a compra de ações ou debêntures conversíveis em ações de sociedades que se habilitassem a cumprir determinadas obrigações de aumento de capital por oferta pública. Os recursos eram arrecadados e geridos por instituições financeiras, que tinham a obrigação de entregar ao investidor um certificado de compra de ações. O sistema ficou conhecido como fundo fiscal 157, ou apenas, fundo 157, dando bem a ideia do quanto a utilização do vocábulo fundo era usada para identificar recursos aportados dentro de uma companhia."

${ }^{44}$ Tais fundos foram constituídos em lei e eram administrados por órgãos da Administração Pública, mas permitiam o aporte de capital privado, mediante a subscrição, por pessoas naturais ou jurídicas, das cotas de sua emissão. O maior atrativo desse tipo de investimento era a possibilidade de deduzir, observados os limites estipulados no artigo 11 do referido Decreto-lei, parcelas do imposto de renda das pessoas jurídicas desde que estas utilizassem os recursos oriundos de tais descontos para adquirir cotas dos fundos, cujo principal objetivo era fomentar determinados setores da economia em regiões estratégicas.
} 
Outros fatores significantes para a proliferação dos fundos de investimento no Brasil nos anos de 1990 foram a possibilidade de capital estrangeiro adquirir cotas de fundos nacionais, conforme autorizado pelo Comunicado-Conjunto do Banco Central do Brasil e da Comissão de Valores Mobiliários $n^{\circ}$ 43, de 11 de março de 1992, bem como a criação de fundos para aplicação em títulos e valores mobiliários lastreados em operações de commodities realizadas em mercados de bolsa e de balcão organizado.

Sendo incontestável a consolidação da indústria dos fundos de investimento enquanto um dos pilares que sustenta o mercado financeiro no contexto econômico brasileiro, a competência para regular e fiscalizar o setor, no entanto, abria margem para questionamentos, pois, desde a Lei $\mathrm{n}^{\circ} 4.728 / 65$, o órgão competente para editar normas relativas a fundos era o Conselho Monetário Nacional (CMN). Ocorre que, a partir da criação da Comissão de Valores Mobiliários (CVM) pela Lei nº 6.385, de 7 de dezembro de 1976, foram revistas as funções tanto do CMN, quanto do Banco Central e da própria CVM.

Nesse sentido, o que se viu, na prática, foi a atuação isolada de cada um desses órgãos, no exercício de sua prerrogativa de criar normas regulamentares com força de lei, de modo a serem editadas regras distintas para tratar do mesmo assunto. Com isso, passou-se a existir, do ponto de vista regulamentar, diversos tipos diferentes de fundos, alguns regulados pelo Banco Central, outros pela CVM, sem que houvesse qualquer sinergia de esforços por parte de ambos os órgãos para que tais regras fossem compatíveis entre $\mathrm{si}^{45}$. O resultado dessa

\footnotetext{
45 "Banco Central e CVM, nos diversos tipos de fundos de investimento que instituíram ao longo dos anos, sempre trataram de forma nitidamente distinta regras elementares como constituição e registro dos fundos, emissão e resgate de cotas, diversificação de risco e alavancagem da carteira, vedações legais, publicidade de informações, elaboração de demonstrações financeiras e auditoria e, inclusive, obrigações do administrador." (FREITAS, Ricardo dos Santos. 2005. p. 94)
} 
dupla competência para regular fundos foi a divisão do gênero em dois grandes grupos: os fundos do Banco Central e os fundos da CVM.

Tal dicotomia só encontrou fim com a promulgação da Lei ${ }^{\circ} 10.303$, de 31 de outubro de 2001, responsável por alterar a Lei $\mathrm{n}^{\circ}$ 6.404, de 15 de dezembro de 1976, quando ficaram expressamente classificadas como valores mobiliários as cotas de fundos de investimento, cabendo, portanto à CVM a competência exclusiva para regular, de forma irrestrita, o assunto. Dessa forma, no intuito de compor um único bloco de normas aplicáveis aos fundos de investimento, a CVM e o Banco Central firmaram, em 5 de julho de 2002, um convênio visando à troca de informações, bem como outras providências necessárias para efetivar tal processo de adaptação.

Dessa forma, em 18 de agosto de 2004, entrou em vigor a Instrução da $\mathrm{CVM} \mathrm{n}^{\circ} 409$, refletindo o trabalho conjunto decorrente do convênio celebrado entre a autarquia e o Banco Central, dado que todas as espécies de fundo reguladas e fiscalizadas por este se viram obrigadas a adequar-se ao disposto na nova regulamentação, tendo sido estipulado como prazo-limite para a implementação de eventuais alterações o dia 31 de janeiro de 2005, momento em que deixaram de vigorar as normas editadas pelo Banco Central para os fundos de investimento em funcionamento no Brasil. 


\section{A INSTRUÇÃO DA CVM № 555, DE 17 DE DEZEMBRO DE 2014}

Os fatores que levaram a CVM a editar uma nova norma geral para os fundos de investimentos, assim compreendida a Instrução da CVM no 555 , de 17 de dezembro de 2014, conforme alterada, foram, dentre outros, a necessidade de atualizar e refletir na regulamentação então vigente as orientações emanadas dos Ofícios-Circulares da Superintendência de Relações com Investidores Institucionais, os entendimentos manifestados pelo Colegiado, bem como as questões solucionadas em sede de julgamento de processos administrativos sancionadores e demais precedentes já pacificados na CVM. Adicionalmente, a estrutura normativa da Instrução CVM 409 demandava certa reciclagem para se ajustar à diversas alterações em seu texto sofridas ao logo de mais de uma década em vigor.

Em associação a tais motivações, nos termos do Edital de Audiência Pública n o 04/2014 da CVM, a edição da Instrução CVM 555 tinha por objetivo "modernizar as regras aplicáveis aos fundos de investimento em diversos aspectos, em especial: (i) a valorização dos meios eletrônicos de comunicação; (ii) a racionalização do volume e forma de divulgação de informações; (iii) a maior transparência no que se refere à política de distribuição; (iv) a vedação ao recebimento de remuneração que prejudique a independência na gestão do fundo; (v) o aprimoramento da regulação no que se refere à taxa de performance; e (vi) a flexibilização dos limites de aplicação em determinados ativos financeiros, sobretudo no exterior".

Em relação ao primeiro ponto, a nova regulamentação põe fim à necessidade de aprovação prévia do cotista para que as comunicações relativas ao fundo fossem feitas por meio eletrônico, como era disciplinado anteriormente 
pela Instrução CVM 409, o que impunha custos desnecessários ao funcionamento do fundo, em especial àqueles caracterizados pela alta dispersão no mercado, dificultando a obtenção da anuência de todos os cotistas para que o meio eletrônico pudesse ser utilizado como canal de comunicação. Dessa forma, bastando que tal autorização conste expressamente no regulamento do fundo, o administrador e/ou gestor passaram a poder adotar meios eletrônicos em comunicações com os cotistas, bem como disponibilizar documentos e informações na rede mundial de computadores.

Quanto à racionalização do volume e da forma de divulgação de informações, a Instrução CVM 555 deu um novo tratamento ao assunto, no sentido de otimizar as exigências legais para divulgação de informações e disponibilização de documentos, apoiada nos frequentes relatos de investidores comuns que possuíam dificuldade em localizar informações específicas dos fundos por conta do volume de documentos. Nessa linha, optou-se por excluir a necessidade de apresentação de prospecto para fundos abertos, tendo suas informações mais relevantes sido realocadas para o termo de adesão e ciência de risco, principalmente no que tange aos fatores de risco relacionados ao fundo. Atualmente, as demais informações necessárias podem ser consultadas em um novo documento virtual denominado "Formulário de Informações Complementares do Fundo".

Este novo documento também passou a abarcar determinadas informações antes constantes do regulamento do fundo, como, por exemplo, descrições da política de voto decorrente dos ativos do fundo, da tributação aplicável e da política de administração de risco, sob o argumento de que, por sua natureza mais dinâmica, tais informações são objeto de mudanças com frequência, o que enseja a necessidade de alterar o regulamento e, consequentemente, convocar assembleia de cotistas para deliberar nesse sentido. 
Um terceiro aspecto que foi substancialmente alterado em razão da edição da Instrução CVM 555 foi a vedação ao pagamento de remuneração de rebate na taxa de administração de um fundo. Tratava-se da situação em que um fundo recebia recursos de um segundo fundo (este, um fundo de cotas ou fundo de fundo), em razão da subscrição de cotas de emissão daquele. $\mathrm{O}$ administrador do fundo investido, portanto, repassava parte da sua taxa de remuneração ao administrador do fundo investidor/cotista, conforme autorizado pelo artigo 65A, parágrafo único, da antiga Instrução CVM $409^{46}$.

Esse tipo de repasse foi introduzido à regulamentação dos fundos de investimento no Brasil em um momento em que ainda não havia sido estipulada a possibilidade de distribuição por conta e ordem, em que a instituição integrante do sistema de distribuição de valores mobiliários atua por conta e ordem de seus clientes, adquirindo em nome destes as cotas dos fundos que visa a distribuir no mercado. Dessa forma, era necessário que tal instituição financeira constituísse um fundo destinado a investir em cotas de outros fundos distribuídos por tal instituição para que, então, os investidores pudessem aplicar seus recursos diretamente no fundo recém-criado e, indiretamente, nos demais fundos disponíveis para aplicação no banco. De modo a repassar a remuneração ao distribuidor, instituiu-se, portanto, o mecanismo de rebate da taxa de administração do fundo investido.

Contudo, uma vez prevista na regulamentação então vigente a atuação do distribuidor por conta e ordem ${ }^{47}$, deixou de fazer sentido manter a estrutura de remuneração por rebate da taxa de administração para os fundos investidos por

\footnotetext{
46 “Art. 65-A: O administrador e o gestor devem transferir ao fundo qualquer benefício ou vantagem que possam alcançar em decorrência de sua condição, admitindo-se, contudo, que o administrador e o gestor de fundo de cotas sejam remunerados pelo administrador do fundo investido." (grifei)

${ }^{47}$ Art. 33 da Instrução CVM 409.
} 
outros fundos. A preocupação do regulador foi no sentido de evitar potenciais conflitos de interesses resultantes de decisões de investimento por parte do administrador ou gestor do fundo motivadas exclusivamente em maiores remunerações de rebate oferecidas pelos diferentes fundos disponíveis para investimento. Outro fator que motivou tal vedação foi o fato de que o investidor não possuía acesso a informações quanto aos custos de distribuição ${ }^{48}$.

No novo texto regulamentar, no entanto, foi feita a ressalva de que, a vedação ao repasse de recurso por parte do administrador não valerá para os fundos de fundos que invistam mais de $95 \%$ de sua carteira em um mesmo fundo de investimento. O racional consiste na ideia de que, nesse caso, fica evidente a intenção do distribuidor de simplesmente replicar a carteira do fundo investido, não havendo sequer o que falar em termos de remuneração de rebate e eventuais conflitos de interesse dela decorrentes, pois a própria política de investimento do fundo já delimita o escopo de aplicação de seus recursos especificamente e tão somente àquele fundo investido (o pagamento de um rebate maior por outro fundo não faria com que o administrador ou gestor realocasse as aplicações do fundo investidor).

Em paralelo, a Instrução CVM 555 também inovou no sentido de reconhecer um terceiro método de cálculo da taxa de performance a ser paga pelo fundo ao administrador ou ao gestor, conforme o caso. Anteriormente, já eram admitidos os métodos do ativo (por meio do qual a performance é metrificada de acordo com a valorização dos ativos do fundo) e do passivo (ou do certificado, por meio do qual a performance é calculada por cada cotista individualmente, mas cobrada coletivamente e suportada integralmente pelo

\footnotetext{
${ }^{48}$ Por meio do Edital de Audiência Pública nº 04/2014, a CVM expôs, ainda, que a proibição da remuneração de rebate se justificava, pois tal prática "reduzia o estímulo para uma maior competição entre diferentes distribuidores e também diferentes administradores.
} 
fundo). Com a nova regulamentação, passou a ser aceito o método do ajuste, que, embora mais complexo, é mais eficaz no sentido de corrigir eventuais desvios de cálculos e, logo, pagamentos imprecisos pelo fundo ao administrador ou ao gestor, uma vez que leva em consideração ajustes individualizados para cada aplicação feita no fundo.

Outras novidades apresentadas pela referida Instrução neste tema incluem: (i) a vedação ao reset; (ii) a definição de como deve ser calculada a taxa de performance quando a cota do fundo se valoriza e o índice de referência (benchmark) cai no mesmo período de cobrança; e (iii) a inclusão da linha d'água também para os investidores qualificados.

Já quanto à classificação dos fundos de investimento, a Instrução CVM 555 , refletindo a preocupação do regulador em estimular um mercado de fundos mais simplificado e eficaz, reduziu de sete para quatro a quantidade de categorias entre as quais se classificam os fundos regulados pela referida norma. Os antigos grupos de fundos "referenciados" e "de curto prazo" passaram a ser considerados uma subcategoria do grupo "renda fixa", assim como a classe "dívida externa" agora é compreendida como uma derivação do grupo de fundos "cambiais".

No que tange aos limites de investimento em determinados ativos financeiros, a nova Instrução também representou certos avanços, tendo em vista que flexibilizou os limites de investimento para fundos destinados exclusivamente a investidores qualificados (além de estabelecer limites ainda mais altos para fundos destinados exclusivamente a investidores profissionais) e aumentou os limites de concentração estipulados para aplicações em ativos financeiros no exterior. 
Justamente em razão dessa última alteração, de modo a remediar antecipadamente maiores riscos assumidos pelos fundos de investimento em decorrência de uma alocação mais significativa de sua carteira em ativos financeiros no exterior, o regulador teve a preocupação de tornar mais rígidas as regras relativas ao serviço de custódia para tais ativos negociados em mercados estrangeiros. Primeiramente, estendeu-se ao custodiante nacional a responsabilidade pelo ativo financeiro no exterior, sem prejuízo dos deveres e garantias assumidos pela instituição custodiante estrangeira. Além disso, caso o gestor brasileiro seja o mesmo que no fundo de investimento do exterior, as carteiras devem ser consolidadas, como ocorreria se ambos os fundos fossem nacionais. Tratando-se de gestores diferentes, o gestor brasileiro deverá adotar as medidas necessárias para assegurar que: (i) o fundo de investimento estrangeiro está sujeito à fiscalização de autoridade local reconhecida pela CVM; (ii) as formas de divulgação e cálculo do valor das cotas do fundo estrangeiro são compatíveis com as do fundo brasileiro; e (iii) o fundo investido é administrado e gerido por profissionais devidamente autorizados e registrados para exercer suas funções de acordo com as regras do mercado onde atuam.

Por fim, a Instrução CVM 555, enquanto novo diploma normativo de aplicação aos fundos de investimento que atuam no mercado brasileiro, de forma geral, também trouxe alterações significativas nos seguintes assuntos: (i) melhorias na comunicação entre distribuidor e cliente em relação ao regime de distribuição por conta e ordem; (ii) dilação do prazo para verificação de quadro de iliquidez, determinando seu fechamento em assembleia de cotistas convocada especificamente para esse fim; (iii) a adoção de regras mais rígidas para a elaboração de lâminas contendo as principais informações do fundo, a serem distribuídas a potencias investidores; (iv) a possibilidade de o administrador divulgar o valor da cota e do patrimônio líquido do fundo em periodicidade compatível com a liquidez do fundo, em vez de fazê-lo diariamente; (v) o 
reconhecimento de certas prerrogativas a fundos destinados a investidores qualificados, de modo a aproximar seu regramento daquele dispensado a fundos estruturados; e (vi) a autorização para transformação de fundos que possuam políticas de investimento compatíveis.

Nesse sentido, indiferentemente de eventual juízo de valor a ser associado a cada uma dessas alterações propostas pela nova regulamentação dos fundos de investimento, um ponto é certo: a Instrução CVM 555, no intuito de promover um mercado de fundos de investimento mais célere, descomplicado e eficiente, trouxe mudanças que já surtem seus efeitos na dinâmica do mercado de capitais nacional, impondo que os agentes de mercado ajustem suas respectivas condutas a essa nova realidade. Se o regulador foi bem-sucedido em sua proposta e se inovações dela decorrentes geraram um impacto positivo nas práticas de mercado brasileiras, será objeto de exame mais adiante, no próximo Capítulo deste trabalho. 


\section{POTENCIAIS REFLEXOS PARA O MERCADO FINANCEIRO}

Antes de se expor as reações do mercado financeiro esperadas em decorrência das inovações implementadas para os fundos de investimento por força da edição da Instrução CVM 555, cabe dar dimensão ao atual tamanho do segmento afetado por tais alterações. Para tanto, é válido reproduzir as informações disponibilizadas pela ANBIMA em sua carta de resposta à Audiência Pública no 04/2014 da CVM:

“(...) desde 2004, quando foi editada a Instrução CVM no 409, a indústria brasileira de fundos de investimento passou por inúmeras mudanças, registrando uma significativa evolução.

Os ativos sob gestão saltaram de $\mathrm{R} \$ 629,8$ bilhões em dezembro de 2004 para $\mathrm{R} \$ 2,5$ trilhões em junho de 2014, praticamente quadriplicando em termos nominais (e duplicando em termos reais). O número de fundos, por sua vez, saltou de aproximadamente 3 mil para mais que 8 mil, no caso dos fundos de investimento convencionais, e de aproximadamente 2 mil para praticamente 6 mil, no caso dos fundos em cotas.

Com esse crescimento, os fundos passaram a desempenhar o papel de protagonista em diversos segmentos do sistema financeiro brasileiro: em maio de 2014, 41,3\% do estoque da dívida pública federal em mercado estavam nas mãos desses veículos, e, se consideradas as operações compromissadas na carteira dos fundos, o valor das operações envolvendo títulos públicos federais alcançou o equivalente a $73 \%$ desse estoque. Já no mercado de capitais, $30,1 \%$ do volume negociado em ações na BM\&FBOVESPA em junho de 2014 foi oriundo de operações realizadas por fundos, enquanto no segmento de debêntures (ex-leasing), a participação dos fundos representou $35,4 \%$ do estoque destes ativos na CETIP.

Enquanto isso, somente no varejo, o número de cotistas, medido pelo número de contas que aplicam em fundos de investimento, atingiu 3,8 milhões em maio de 2014, superando largamente o número de investidores que acessam títulos públicos ou ativos oferecidos na BM\&FBOVESPA diretamente (378 mil e 592 mil, respectivamente).

O Brasil saiu, então, da $13^{\mathrm{a}}$ posição no ranking global de indústrias de fundos de investimento para a $6^{\mathrm{a}}$ posição, consolidando-se como uma das principais indústrias de fundos do mundo." 
Dessa forma, elaborada em um cenário de franca expansão do mercado de capitais brasileiro, a Instrução CVM 555, embora tenha entrado em vigor recentemente, já faz suas alterações serem sentidas pelo mercado, não obstante o fato de que parte dos fundos de investimento atualmente em funcionamento ainda esteja em processo adaptação de suas práticas às novas disposições da referida Instrução ${ }^{49}$.

De modo geral, pode-se afirmar que a maior parte das alterações, quando comparado o novo diploma com a Instrução CVM 409, norma anteriormente vigente, foram no sentido de desvencilhar a administração e a gestão do fundo de investimento de determinadas obrigações que, dadas as atuais circunstâncias do mercado, deixaram de fazer sentido, como, por exemplo, a necessidade de enviar comunicações aos cotistas somente por via física, salvo se obtida autorização do cotista para que tal medida seja efetuada pela via eletrônica.

Mais do que reduzir custos e otimizar processos, essa mudança reflete a disposição da CVM em aceitar uma nova realidade de mercado já dominada pela presença de tecnologias de comunicação que tornam o meio eletrônico, de fato, o mais usual entre seus operadores. Claro que, justamente por permitir que administradoras constituam fundos já contando com uma previsão em seus respectivos regulamentos autorizando a comunicação eletrônica, essa novidade especificamente é vista com bons olhos pelo mercado neste momento de retração da economia brasileira. Os retornos menos promissores das aplicações motivam os investidores a buscar estruturas de investimento mais enxutas, livres de gastos desnecessários.

\footnotetext{
${ }^{49}$ Nos termos do artigo 150 da Instrução CVM 555, os fundos de investimento em funcionamento na data de início de sua vigência têm até o dia 30 de junho de 2016 para se adaptar às suas disposições.
} 
Sob este mesmo ângulo deve ser examinada a nova regra em relação à divulgação do valor da cota e do patrimônio líquido do fundo, agora em uma periodicidade definida de acordo com os padrões de liquidez do fundo, não sendo mais necessário divulgar tais informações diariamente. Ora, se de fato, o quadro de liquidez das cotas do fundo não requer que o cotista tenha ciência do valor da cota e do patrimônio líquido, o levantamento e a divulgação de tais informações em bases diárias perde sentido, não passando de mero inconveniente imposto pela vontade míope do regulador.

Por tais razões, é possível prever que o mercado não obstaculize adaptações nesse sentido, ressalvado o fato de que, pela redação do artigo 56, inciso $\mathrm{I}$, alínea $\mathrm{b}$, da Instrução $\mathrm{CVM} 555^{50}$, fica totalmente sujeito à discricionariedade do administrador estipular no regulamento do fundo a periodicidade com que tal informação será divulgada, sem que tal juízo de valor esteja vinculado a quaisquer parâmetros de liquidez para determinar uma periodicidade recomendada.

Outro ponto importante ainda sobre esse tema foi a eliminação do prospecto para fundos abertos. Aqui novamente o regulador se viu na necessidade de balizar a otimização de informações e uma melhor operacionalização do fundo com a tarefa de proteger os interesses dos cotistas. Seguindo essa lógica, quanto mais branda a obrigação de divulgar informações pela entidade que recebe recursos, mais desprotegido estaria o investidor que nela os aplica. No entanto, nesse caso específico, a exclusão do dever de elaborar prospecto para fundos abertos já era fortemente demandada por agentes

\footnotetext{
50 “Art. 56. O administrador do fundo é responsável por:

I - calcular e divulgar o valor da cota e do patrimônio líquido do fundo aberto:

a) diariamente; ou

b) para fundos que não ofereçam liquidez diária a seus cotistas, em periodicidade compatível com a liquidez do fundo, desde que expressamente previsto em seu regulamento; $(\ldots)^{\prime}$
} 
integrantes da indústria de fundos de investimento e, levando-se em consideração que as informações mais relevantes do prospecto continuam disponibilizadas aos investidores em outros documentos, não há que se falar em prejuízo decorrente da supressão do material.

Em relação aos novos limites de investimento para fundos destinados exclusivamente a investidores qualificados e a investidores profissionais, embora as expectativas do mercado não tenham sido integralmente atendidas, deve-se reconhecer como bem-vindo o fato de a CVM ter dado tratamento ainda mais distinto e individualizado aos grupos de investidores de acordo com a disponibilidade de seus recursos e, consequentemente, nível de experiência em investimento e processamento de informações - dessa forma, fundos destinados a investidores de varejo seguem sujeitos a limites de investimento mais severos, ao passo que se tornam mais flexíveis quando os públicos-alvo dos fundos são investidores qualificados e profissionais.

Nessa linha, igual reação poderá ser registrada no mercado em razão do aumento nos limites de concentração estipulados para aplicações em ativos financeiros no exterior, novamente de acordo com o enquadramento do investidor em um dos grupos: de varejo, qualificados e profissionais. Adicionalmente, pode-se concluir que uma orientação do regulador mais aberta à possibilidade de realização de investimentos no exterior reflete uma tendência de integração dos mercados de capitais ao redor do mundo cada vez mais forte, como um dos efeitos de um mundo mais globalizado e interconectado. Tanto o é, que a permissão para que fundos de investimento apliquem em ativos negociados no exterior é uma tendência entre as autoridades reguladoras dos mercados de outros países. Afinal, há nítido interesse entre seus participantes que lhes seja possível diversificar suas carteiras com opções de investimento 
diversas das encontradas em seu mercado doméstico (comportando, consequentemente, riscos diversos para seus portfólios).

Por outro lado, a maior exposição a riscos de ativos estrangeiros motivou a CVM a aperfeiçoar as regras impostas ao administrador e ao custodiante brasileiros em relação à instituição custodiante estrangeira, impondo obrigações adicionais e mais efetivas àqueles e incluindo novos critérios para $\mathrm{o}$ reconhecimento desta, o que, por um lado, pode ser compreendido como uma medida protetiva, mas, ao mesmo tempo, um movimento de burocratização dispensável.

Outro avanço da nova regulamentação foi o reconhecimento de um terceiro método para o cálculo da taxa de performance do fundo. Mesmo antes de a Instrução CVM 555 entrar em vigor, embora mais complexa, alguns fundos já praticavam essa forma eficaz de calcular sua taxa de performance, no intuito de evitar eventuais distorções patrimoniais para os cotistas entre si e também entre estes e o administrador ou gestor, conforme o caso. Dessa forma, pode ser entendida como positiva a postura da autoridade reguladora no sentido de tipificar e padronizar a prática já adotada pelo mercado de utilizar o método de ajuste na definição da taxa de performance do fundo.

Adicionalmente, de acordo com regulamentação atualmente em vigor, os fundos foram redistribuídos em quatro categorias, de acordo com as características de suas respectivas carteiras, criando subcategorias que denotam fundos com atribuições mais específicas, o que aproxima mais o regramento brasileiro das práticas internacionais, além de tornar mais simples para o investidor a identificação do produto que melhor se adeque ao seu perfil. 
Por fim, se, por um lado, a nova Instrução representa avanços significativos em pontos cujas mudanças já eram demandadas pelo mercado anteriormente, por outro lado, já em resposta à Audiência Pública da minuta de Instrução, ela foi alvo de críticas de entidades integrantes do mercado de capitais, representadas pela ANBIMA, por extinguir a remuneração de rebate.

Ainda que seja bem fundamentada a posição do regulador para essa questão, com vistas à sua constante preocupação em manter o mercado atuando em condições justas de negociação, deve-se reconhecer que um dos principais fatores responsáveis por alimentar o desenvolvimento acelerado da indústria de fundos de investimento foi a expansão das operações de distribuição de cotas de fundos por meio de administradores que neles investiam. Essa prática, antes aplicada restritamente em fundos diretamente relacionados à instituição distribuidora, passou a ser adotada mesmo quando o administrador optava por aplicar os recursos por ele geridos em fundos administrados por outras instituições, alheias ao seu grupo econômico.

A preocupação da CVM foi, portanto, justamente no sentido de evitar que interesses conflitantes surgissem em razão da possibilidade de o administrador do fundo investidor barganhar a decisão por alocar os recursos em determinado fundo de acordo com a remuneração de rebate paga, como se fizesse do patrimônio do fundo verdadeiro leilão com o objetivo de arrematar a taxa de rebate mais alta.

Contudo, deve-se analisar a situação a partir de outro prisma: sendo, nesse caso, ainda mais latentes as regras de livre mercado, se uma instituição financeira recomenda um fundo inadequado ao perfil de seu cliente, apenas com o interesse de receber a taxa de rebate mais alta, está correndo o risco de o investidor resgatar suas aplicações e, consequentemente, perder a respectiva 
remuneração sobre aquela conta. Assim, a decisão de pôr fim à remuneração de rebate pode representar a vedação a uma prática que contribuiu substancialmente para a constituição de um sistema de fundos de investimento extremamente diversificado e interligado, o que, em última análise, beneficia diretamente os investidores.

De qualquer modo, não há como negar que as mudanças impostas por força da edição da Instrução CVM 555 indicam o esforço do regulador no sentido de adaptar suas normas à nova realidade atualmente vivida no mercado financeiro do Brasil, em um cenário marcado por maior competitividade decorrente da pulverização de gestoras e administradoras, maior volume de operações realizadas, inclusive com entidades e ativos localizados no exterior, maior grau de sofisticação das transações e de seus agentes, um aumento na participação dos investidores de varejo e participantes mais preparados a adotar boas práticas de governança.

Além disso, embora, por vezes, tenha entregado aquém do que vem sendo denunciado pelas demandas do mercado e, em outras ocasiões, tenha imposto normas mais rígidas e burocráticas, o sentido geral da nova regulamentação é no sentido de simplificar processos e desvincular a estrutura de um fundo de investimento de custos desnecessários em ditames de baixa utilidade, em uma tentativa razoavelmente bem sucedida de promover o fomento do mercado de capitais brasileiro e incliná-lo à direção adotada por mercados desenvolvidos em suas práticas. 


\section{CONCLUSÃO}

De modo geral, pode-se compreender que os fundos de investimento representam uma complexa estrutura jurídica, representativa de uma comunhão de bens e constituída sob a forma de condomínio (desprovida, portanto, de personalidade jurídica), da qual participam aqueles que subscrevem e integralizam valor mobiliário representativo de uma fração ideal de seu patrimônio, denominado cota. Por ser feixe de diversos direitos e deveres, além de figurar em relações jurídicas das mais diversas naturezas, deve-se atentar para o fato de que o funcionamento de um fundo de investimento pressupõe a atuação de diversas figuras, que agem de acordo com suas responsabilidades segregadas, conforme instituídas pela regulamentação aplicável.

De modo geral, o alto nível de sofisticação, em termos de organização e funcionamento, alcançado pelos fundos de investimento foi precedido e fortemente impactados pelos mais diversos acontecimentos, encadeados entre si, na história recente da economia mundial. Seu surgimento remonta aos mercados europeus do século XVIII e seu desenvolvimento foi substancialmente influenciado pela regulamentação inaugural promovida pelas autoridades inglesas e norte-americanas.

Com o início da era da globalização e a abertura de novos mercados relevantes (incluindo o Brasil) para o sistema financeiro internacional, a dinâmica dos mercados de capitais (e por via de consequência, dos fundos de investimento) passou a enfrentar uma nova realidade: avanços tecnológicos e a pluralidade de opções tornaram as transações internacionais mais frequentes, complexas e instantâneas, o que explica o surgimento de determinados paradigmas (e.g. a adoção de boas práticas de governança corporativa) que 
influenciam constantemente a regulamentação dos fundos de investimento, inclusive no plano nacional.

Nesse mesmo sentido, no contexto brasileiro, suportada por uma plataforma monetária estável (não obstante tardiamente concebida), a evolução do mercado de capitais nacional a partir dos anos de 1990 é notável e a indústria de fundos de investimento foi um dos principais fatores estimulantes de tal desenvolvimento. Superadas incertezas tais como o tratamento fiscal aplicável e a competência regulatória, os fundos de investimento se tornaram um dos principais atores do mercado financeiro pátrio, o que se deveu, de certa forma, a avanços em termos de regulamentação ao longo do século XX no Brasil.

Tendo sido justamente nesse contexto de solidificação das instituições democráticas, maior estabilidade monetária e cambial, associadas ao crescimento econômico decorrente do aquecimento do mercado chinês e de uma maior abertura da economia brasileira ao capital internacional, que se pensou a Instrução CVM 555, revogadora da Instrução CVM 409, a nova norma enfrenta agora o desafio de entrar em vigor em um contexto substancialmente diverso: o Estado brasileiro passa por um processo de impeachment presidencial, a economia se encontra em quadro de recessão, agravada pela desaceleração das atividades na China e abatida por um rol de índices e resultados de contas públicas apontando o descontrole das autoridades estatais quanto aos rumos econômicos do país.

Não obstante e, mesmo não tendo atendido integralmente às demandas do mercado, de modo geral, pode-se concluir que as novidades trazidas pela referida Instrução refletem justamente uma preocupação do regulador em fomentar a indústria dos fundos de investimento tornando-a mais eficiente e adequada aos padrões internacionais. 


\section{REFERÊNCIAS BIBLIOGRÁFICAS}

EIZIRIK, Nelson et al. Mercado de Capitais: Regime Jurídico. 3. ed. Rio de Janeiro: Renovar, 2011.

FREITAS, Ricardo de Santos. Natureza Jurídica dos Fundos de Investimento. São Paulo: Quartier Latin, 2005.

FORTUNA, Eduardo. Mercado Financeiro: Produtos e Serviços. 19. ed. Rio de Janeiro: Qualitymark Editora, 2014

VELLOSO, José Paulo dos Reis et al. A modernização do capitalismo brasileiro: reforma do mercado de capitais. Rio de Janeiro: José Olympio, 1991.

CHESNAIS, François. A mundialização do capital; tradução Silvana Finzi Foá. São Paulo: Xamã, 1996.

BACHA, Edmar Lisboa; FILHO, Luiz Chrysostomo de Oliveira et al. Mercado de capitais e crescimento econômico: lições internacionais, desafios brasileiros. Rio de Janeiro e São Paulo: Contra Capa Livraria, ANBID, 2005.

FABOZZI, Frank $\mathbf{J}$ et al. Foundations of financial markets and institutions. Englewood Cliffs, New Jersey: Prentice-Hall, 1994.

CORDONIZ, Gabriela; PATELLA, Laura et al. Comentários à Lei do Mercado de Capitais $n^{o}$ 6.385/76. São Paulo: Quartier Latin, 2015.

LEITÃO, Miriam. Saga brasileira: a longa luta de um povo por sua moeda. 4. ed. Rio de Janeiro: Record, 2011 
ARAÚJO, Eugênio Rosa de. Direito econômico. 4. ed. Niterói: Impetus, 2010.

CARDOSO, Fernando Henrique. Mãos à obra Brasil: proposta de governo. Brasília: s. ed., 1994. 